\section{Pacific Northwest}

National Laboratory

Operated by Battelle for the

U.S. Department of Energy

\title{
Screening of Potential Remediation Methods for the 200-BP-5 Operable Unit at the Hanford Site
}

\author{
M. J. Truex \\ P. E. Dresel \\ M. J. Nimmons \\ C. D. Johnson
}

September 2006

Prepared for the U.S. Department of Energy under Contract DE-AC05-76RL01830 


\title{
DISCLAIMER
}

This report was prepared as an account of work sponsored by an agency of the United States Government. Neither the United States Government nor any agency thereof, nor Battelle Memorial Institute, nor any of their employees, makes any warranty, express or implied, or assumes any legal liability or responsibility for the accuracy, completeness, or usefulness of any information, apparatus, product, or process disclosed, or represents that its use would not infringe privately owned rights. Reference herein to any specific commercial product, process, or service by trade name, trademark, manufacturer, or otherwise does not necessarily constitute or imply its endorsement, recommendation, or favoring by the United States Government or any agency thereof, or Battelle Memorial Institute. The views and opinions of authors expressed herein do not necessarily state or reflect those of the United States Government or any agency thereof.

\author{
PACIFIC NORTHWEST NATIONAL LABORATORY \\ operated by \\ BATTELLE \\ for the \\ UNITED STATES DEPARTMENT OF ENERGY \\ under Contract DE-AC05-76RL01830
}

Printed in the United States of America
Available to DOE and DOE contractors from the Office of Scientific and Technical Information,
P.O. Box 62, Oak Ridge, TN 37831-0062;
ph: (865) 576-8401
fax: (865) 576-5728
email: reports@adonis.osti.gov

\author{
Available to the public from the National Technical Information Service, \\ U.S. Department of Commerce, 5285 Port Royal Rd., Springfield, VA 22161 \\ ph: (800) 553-6847 \\ fax: (703) 605-6900 \\ email: orders@ntis.fedworld.gov \\ online ordering: http://www.ntis.gov/ordering.htm
}




\title{
Screening of Potential Remediation Methods for the 200-BP-5 Operable Unit at the Hanford Site
}

\author{
M. J. Truex \\ P. E. Dresel \\ M. J. Nimmons \\ C. D. Johnson
}

September 2006

Prepared for

the U.S. Department of Energy

under Contract DE-AC05-76RL01830

Pacific Northwest National Laboratory

Richland, Washington 99352 


\section{Summary}

A screening-level evaluation of potential remediation methods for application to the contaminants of concern (COC) in the 200-BP-5 Operable Unit at the Hanford Site was conducted based on the methods outlined in the Guidance for Conducting Remedial Investigations and Feasibility Studies under CERCLA Interim Final (EPA 1988). The scope of this screening was to identify the most promising remediation methods for use in the more detailed analysis of remediation alternatives that will be conducted as part of the full feasibility study. The screening evaluation was conducted for the primary COC (potential major risk drivers) identified in the groundwater sampling and analysis plan for the operable unit (DOE/RL2001-49, Rev. 1) with additions. COC with similar properties were grouped for the screening evaluation.

The screening evaluation was conducted in two primary steps. The initial screening step evaluated potential remediation methods based on whether they can be effectively applied within the environmental setting of the 200-BP-5 Operable Unit for the specified contaminants. In the second step, potential remediation methods were screened using scoping calculations to estimate the scale of infrastructure, overall quantities of reagents, and conceptual approach for applying the method for each defined grouping of COC. Based on these estimates, each method was screened with respect to effectiveness, implementability, and relative cost categories of the Comprehensive Environmental Response, Compensation, and Liability Act (CERCLA) feasibility study screening process defined in the U.S. Environmental Protection Agency (EPA) guidance (EPA 1988).

Based on the screening evaluation criteria, potential remediation methods were comparatively evaluated to identify those most promising for continued evaluation as part of the feasibility study. Only a few methods are applicable to all COC. Thus, identification of the most promising potential remediation methods was categorized by COC group. Multiple scales of application may be useful for the overall remediation efforts in the 200-BP-5 Operable Unit. For this reason, identification of the most promising potential remediation methods was also categorized by the scales of application identified in the effectiveness evaluation criteria. This resulting matrix of most promising potential remediation methods is intended to provide information to support either use of a single remedy or a "treatment train" approach as part of the feasibility study for the 200-BP-5 Operable Unit. 


\section{Contents}

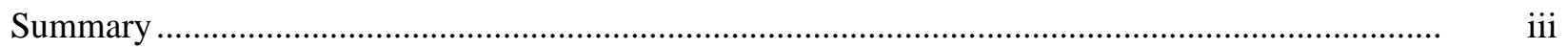

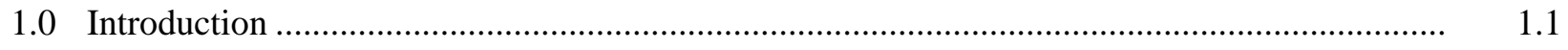

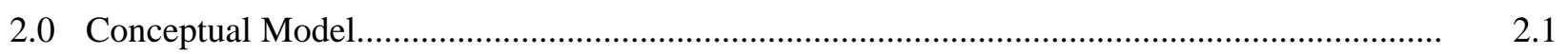

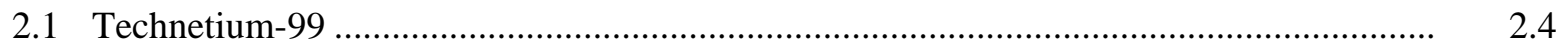

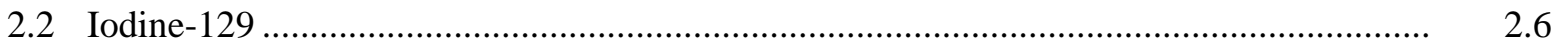

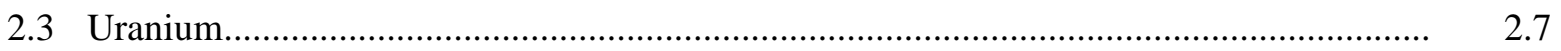

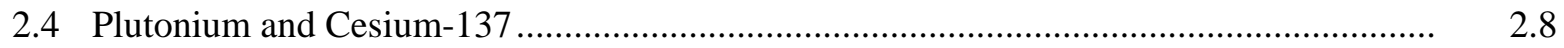

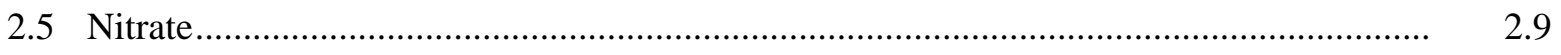

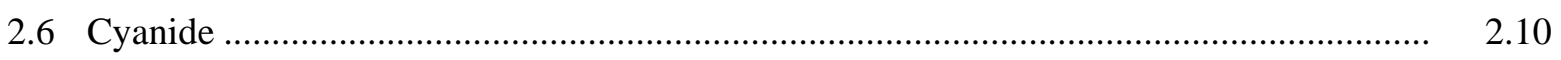

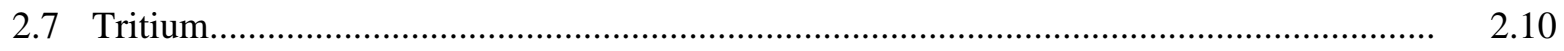

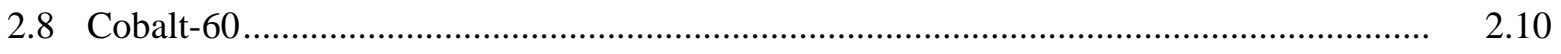

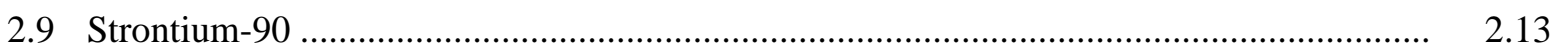

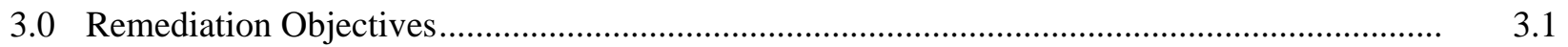

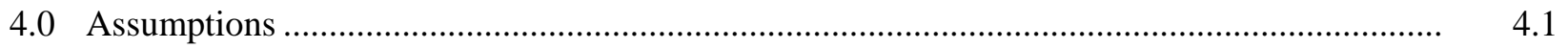

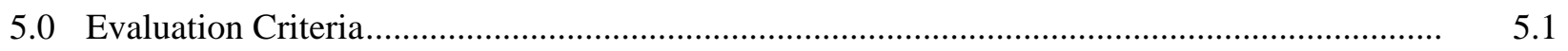

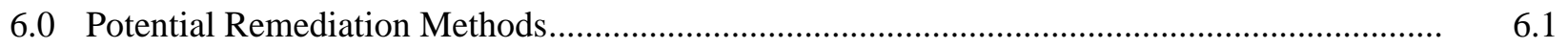

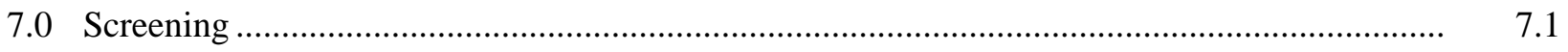

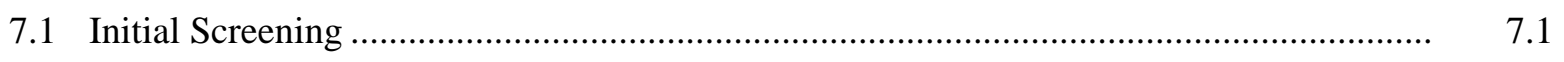

7.2 Screening Based on Scoping Calculations ...................................................................

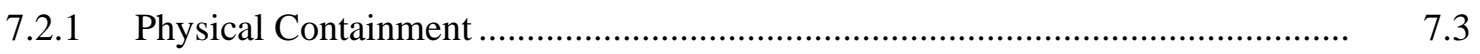

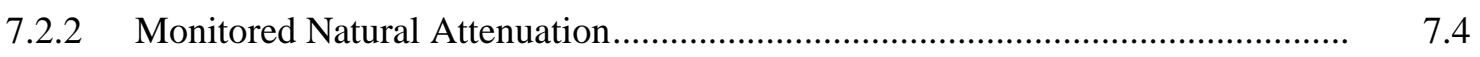

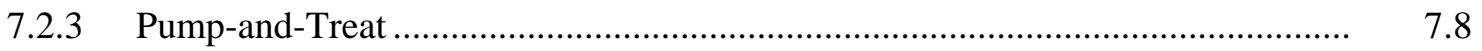

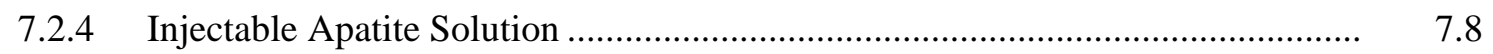

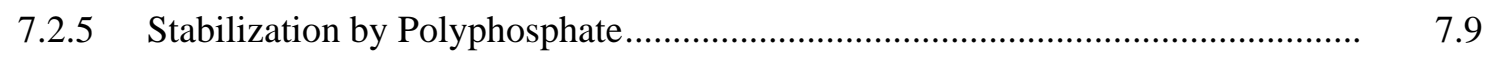

7.2.6 Injectable Zero-Valent Iron ......................................................................... 7.11

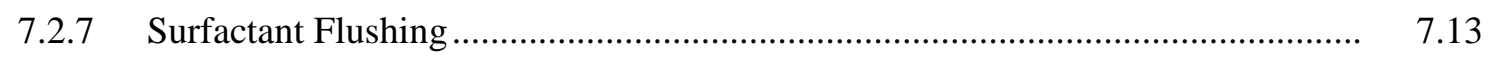

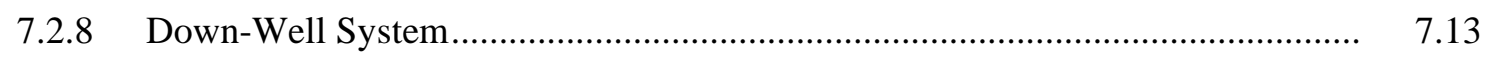

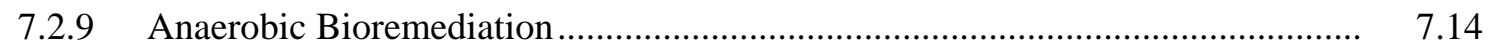

7.2.10 Permeable Reactive Barriers...................................................................... 7.16

8.0 Results of Screening Evaluation ....................................................................................

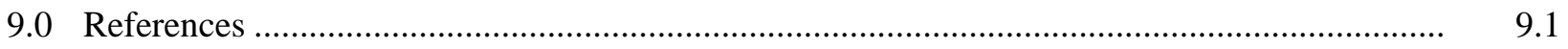




\section{Figures}

2.1 Extent of Major Constituents of Concern at Levels above Drinking Water Standards for the 200-ZP-1 Operable Unit......................................................................................... 2.2

2.2 Elevation of the Top of Basalt Surface ............................................................................... 2.3

2.3 Thickness of Saturated Sediments Forming the Unconfined Aquifer ..................................... 2.3

2.4 Average Technetium-99 Concentrations in 200-East Area, Top of Unconfined Aquifer ......... 2.5

2.5 Average Iodine-129 Concentrations in 200-East Area, Top of Unconfined Aquifer ................ 2.6

2.6 Average Uranium Concentrations in 200-East Area, Top of Unconfined Aquifer .................. 2.7

2.7 Average Nitrate Concentrations in 200-East Area, Top of Unconfined Aquifer .....................

2.8 Average Cyanide Concentrations in 200-East Area, Top of Unconfined Aquifer .................... 2.11

2.9 Average Tritium Concentrations in 200-East Area, Top of Unconfined Aquifer .................... 2.12

2.10 Average Strontium-90 Concentrations in 200-East Area, Top of Unconfined Aquifer ............ $\quad 2.13$

\section{Tables}

1.1 Primary COC Groupings Used in the Screening Evaluation.................................................. 1.1

2.1 Areal Extent Considered in Screening for each Contaminant of Concern ............................... 2.4

2.2 Area and Volume of Technetium-99 Contamination for Remediation Technology Screening

2.3 Area and Volume of Iodine-129 Contamination for Remediation Technology Screening ....... $\quad 2.7$

2.4 Area and Volume of Uranium Contamination for Remediation Technology Screening........... $\quad 2.8$

2.5 Area and Volume of Plutonium and Cesium-137 Contamination for Remediation Technology Screening

2.6 Area and Volume of Nitrate Contamination for Remediation Technology Screening.............. 2.10

2.7 Area and Volume of Cyanide Contamination for Remediation Technology Screening ........... 2.11

2.8 Area and Volume of Tritium Contamination for Remediation Technology Screening............. $\quad 2.12$

2.9 Area and Volume of Cobalt-60 Contamination..................................................................... 2.12

2.10 Area and Volume of Strontium-90 Contamination ............................................................... 2.13

5.1 Screening Evaluation Criteria for the Second Step of Screening ............................................ 5.2

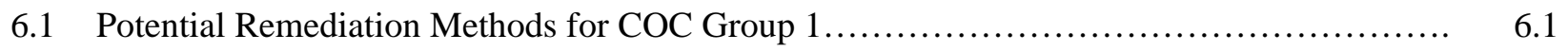

6.2 Potential Remediation Methods for COC Group 2 .................................... 6.2

6.3 Potential Remediation Methods for COC Group 3...................................... 6.2

7.1 COC Group 1 - Remediation Methods Screened Out in Initial Screening ............................. 7.1

7.2 COC Group 2- Remediation Methods Screened Out in Initial Screening ............................... 7.1

7.3 COC Group 3 - Remediation Methods Screened Out in Initial Screening .............................. 7.2

7.4 Remediation Methods Considered in Second Stage of Screening ........................................... 7.2

7.5 Zero-Valent Iron Required as a Function of Aquifer Volume............................................... 7.11 
7.6 Volume of Dithionite Solution as a Function of Treatment Depth.......................................... 7.19

8.1. Summary of Potential Remediation Methods Recommended for Further Assessment for Each COC Grouping Based on the Results of the Screening Evaluation ................................. 


\subsection{Introduction}

A screening-level evaluation of potential remediation methods for application to the contaminants of concern (COC) in the 200-BP-5 Operable Unit at the Hanford Site was conducted based on the methods outlined in the Guidance for Conducting Remedial Investigations and Feasibility Studies under CERCLA Interim Final (EPA 1988). The scope of this screening was to identify the most promising remediation methods for use in the more detailed analysis of remediation alternatives that will be conducted as part of the full feasibility study. The screening evaluation considered the nine potential COC identified in the Groundwater Sampling and Analysis Plan for 200-BP-5 Operable Unit (DOE 2001). These potential COC include technetium-99, iodine-129, cesium-137, cobalt-60, plutonium-239/240, uranium isotopes, tritium, nitrate, and cyanide. Hexavalent chromium is another potential COC due to the presence of significant inventories in waste sites where groundwater has not been monitored to date. Strontium-90 was also considered as a potential COC because it is present above the drinking water standard. Of these potential COC, cesium-137, cobalt-60, and strontium-90 were not considered as COC for the screening evaluation because of the limited extent of contamination and their relatively short radioactive decay halflives. While these contaminants are not considered for the screening evaluation, information about these contaminants is included in the conceptual model portion of this report. The remaining COC selected for the screening evaluation were grouped, as shown in Table 1.1, based on similarity in chemical/physical properties such as mobility and/or, for the most part, the same remediation methods would apply to each contaminant in the group. The screening evaluation includes assessment of whether the potential remediation methods identified for the primary COC have a positive or negative impact on these secondary COC.

Table 1.1. Primary COC Groupings Used in the Screening Evaluation

\begin{tabular}{||l|l||}
\hline \multicolumn{1}{||c||}{ COC Group } & \multicolumn{1}{c||}{ Contaminants } \\
\hline \hline $\begin{array}{l}\text { Group 1 (metals and } \\
\text { radionuclides) }\end{array}$ & $\begin{array}{l}\text { Chromium, technetium-99 (Tc-99), iodine-129 (I-129), } \\
\text { uranium (uranium-234, uranium-235, uranium-238), and } \\
\text { plutonium-239/240 (Pu-239/240) }\end{array}$ \\
\hline Group 2 (non-metals) & Nitrate and cyanide \\
\hline Group 3 (tritium) & Tritium \\
\hline \hline
\end{tabular}




\subsection{Conceptual Model}

A generalized conceptual model of the volume, nature, and extent of contamination and the environmental setting for the 200-BP-5 Operable Unit was developed for use in the screening evaluation. For the purposes of this analysis, the conceptual model addresses the eight COC for which groundwater monitoring data are available. Strontium-90, cesium-137, and cobalt-60 were also included in the conceptual model description because, although they will not be considered as COC, they are present at concentrations above the drinking water standard in the 200-BP-5 area. Chromium is not directly addressed in the conceptual model because groundwater monitoring data do not currently define a plume at concentrations above the action level $(100 \mu \mathrm{g} / \mathrm{L})$. The plume boundaries were selected based on the following concentrations, which are consistent with the anticipated target action levels.

- Technetium-99 (900 pCi/L)

- Iodine-129 (1 pCi/L)

- Uranium (30 $\mu \mathrm{g} / \mathrm{L})$

- Plutonium (1.2 pCi/L)

- Nitrate (45 mg/L as $\mathrm{NO}_{3}$ )

- Cyanide $(200 \mu \mathrm{g} / \mathrm{L})$

- $\operatorname{Tritium}(20,000 \mathrm{pCi} / \mathrm{L})$

- Cesium-137 (200 pCi/L)

- Cobalt-60 (100 pCi/L)

- Strontium-90 (8 pCi/L)

The overall extent of these contaminants at the top of the unconfined aquifer in the 200-BP-5 Operable Unit for fiscal year (FY) 2005 is shown in Figure 2.1. Plutonium, cesium, and cobalt contamination are not shown as plumes because the concentrations of these contaminants above the target level have only been identified in a single well and are believed to be highly localized. Both the area of aquifer with contaminant levels above target action levels and the volume of contaminated aquifer are important for screening of potential remediation methods. In addition, the area and volume containing higher levels of contamination (e.g., source areas) was considered in the screening evaluation.

For the screening of remedial alternatives, it is important to note that the water table is extremely flat within much of the 200-BP-5 Operable Unit. This is due to the high hydraulic conductivity of the Hanford formation sediments and the interaction between regional flow from the west and residual mounding beneath the former B Pond to the east. A groundwater divide is believed to be present in or near the 200-East Area, with flow north of the divide to the northwest, through Gable Gap (between Gable Butte and Gable Mountain), and flow south of the divide to the south east. However, the precise location of the divide is not known and may be variable. The water table is declining, and this decline may lead to future changes in flow directions. If the water table declines sufficiently, the basalt surface may extend above the water table north of the 200-East Area and significantly decrease or eliminate flow through Gable Gap. 


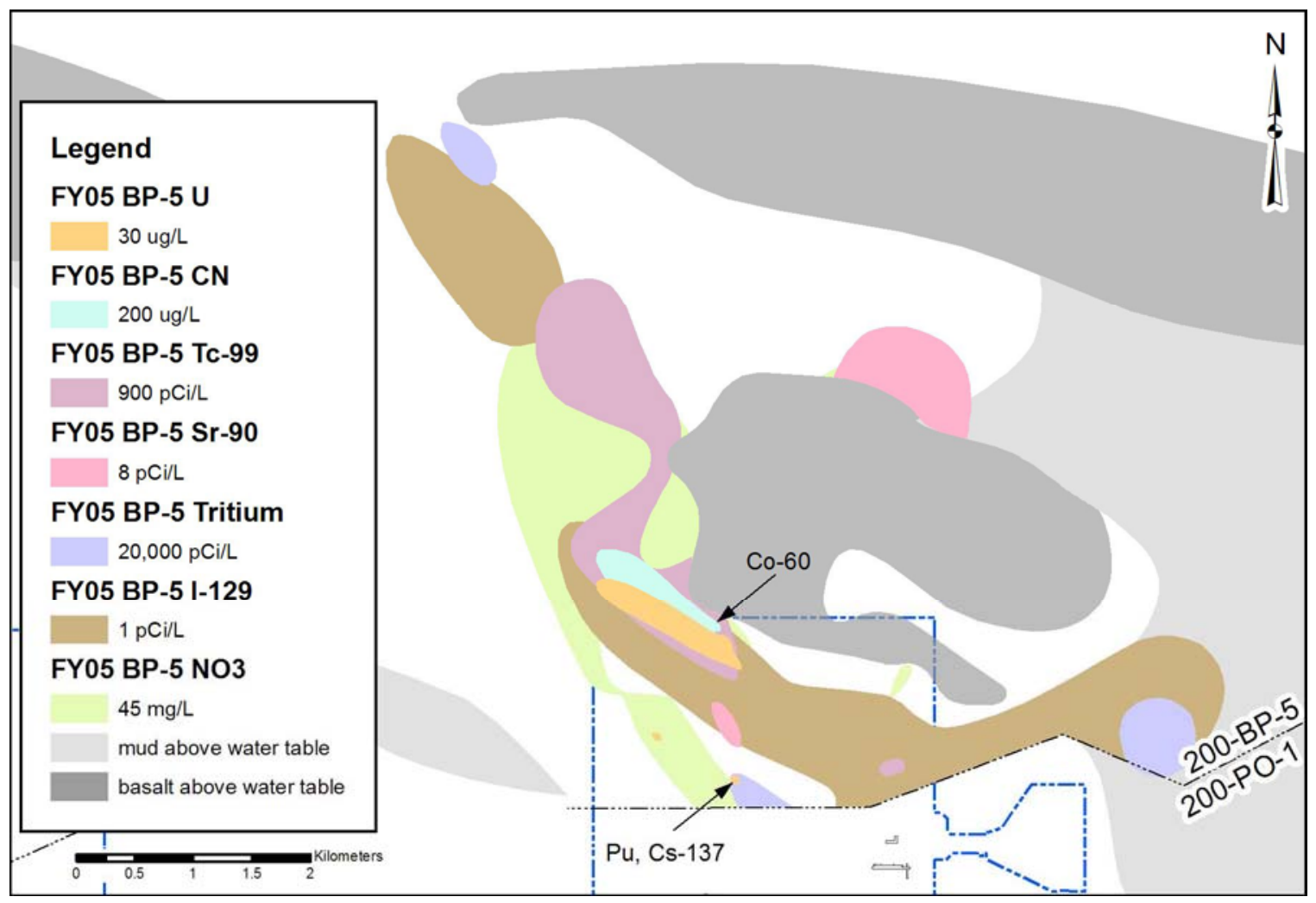

Figure 2.1. Extent of Major Constituents of Concern at Levels above Drinking Water Standards for the 200-ZP-1 Operable Unit (from Hartman et al. 2006)

The conceptual model and associated figures and tables were developed using data from the Hanford Site Groundwater Monitoring for Fiscal Year 2005 (Hartman et al. 2006) except as noted. Specifically, the areal extent of contamination at levels above the target action level and higher levels of concern are calculated from the contamination contours included in Hartman et al. (2006). Average concentrations refer to the average of the data values in Hartman et al. (2006) over the indicated timeframe. There is greater uncertainty in depth of contamination than for the lateral extent at the water table. In general, for most constituents data are insufficient to fully define the three-dimensional extent. The contaminant volume is calculated as being throughout the aquifer, which generally is found in the Hanford formation sands and gravels to the top of Columbia River Basalt Group. There is considerable relief on the top of the basalt in the 200-BP-5 Operable Unit (Figure 2.2). The unconfined aquifer is absent in areas where the basalt surface rises above the water table. The thickness of saturated sediments above the basalt (aquifer thickness) is shown in Figure 2.3. Where the Ringold Formation lower mud unit is present at the water table, the aquifer is confined or semi-confined in underlying sediments. Contaminant plume volumes conservatively include the saturated mud formations in these areas. The basalt surface may be fractured in places, and contamination may be present in the fractures, Rattlesnake Interbed, or confined aquifer system. The amount of contamination present in the fractured basalt, interbed, or confined aquifer were not included for the plume volume calculations. However, more detailed analysis of remediation may need to consider the impact of contamination in the fractures on the effectiveness of remediation. 


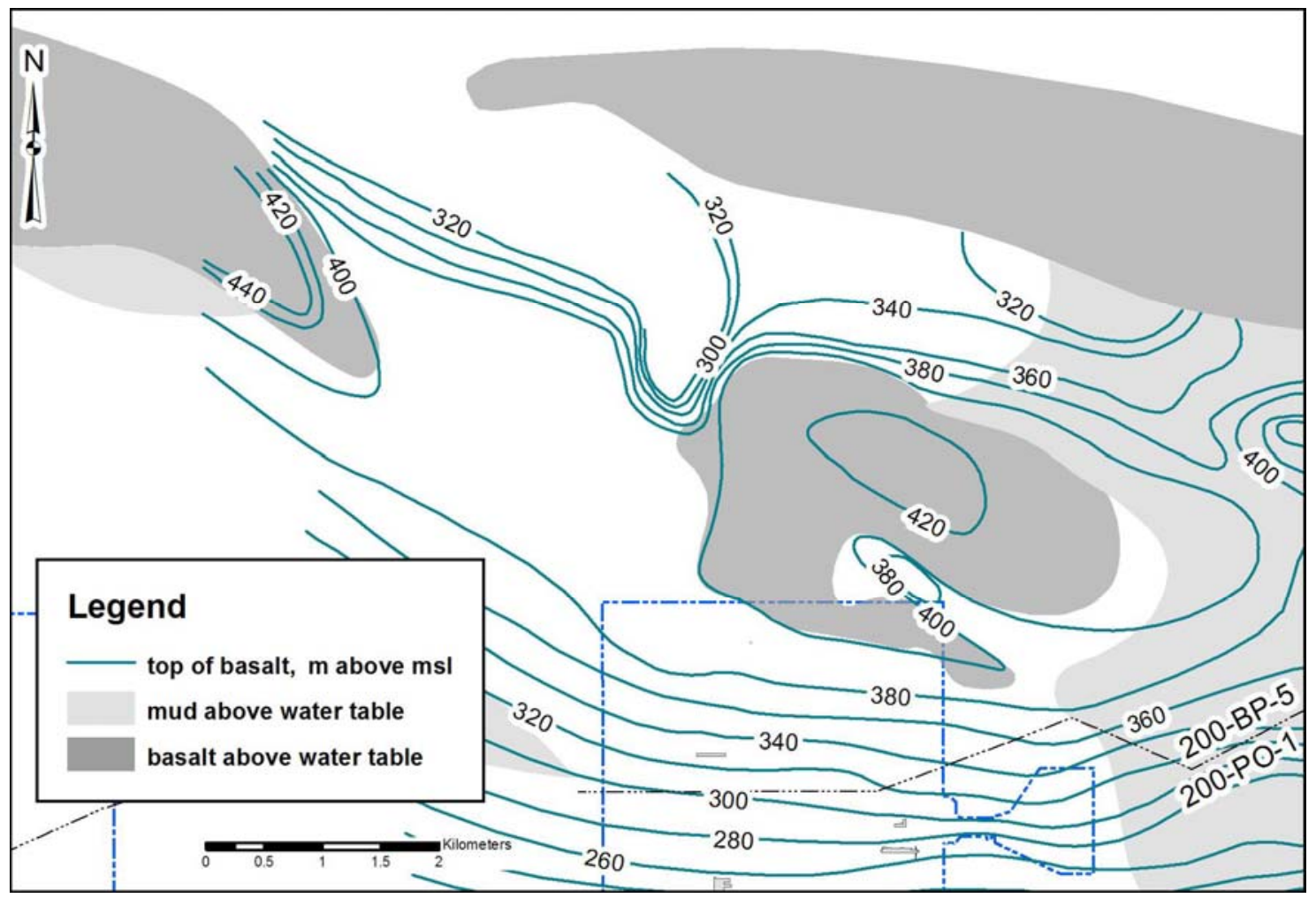

Figure 2.2. Elevation of the Top of Basalt Surface (Williams et al. 2000)

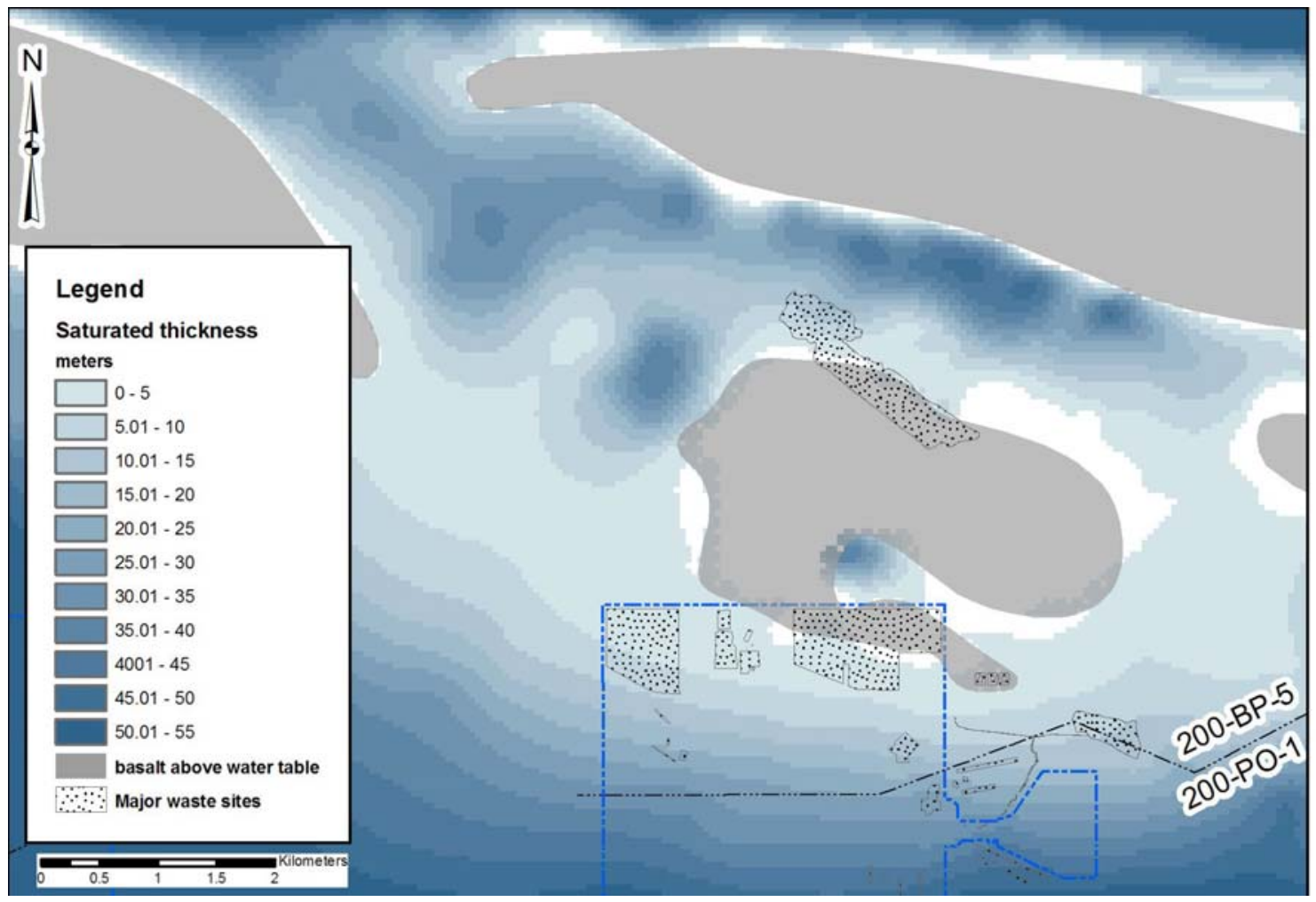

Figure 2.3. Thickness of Saturated Sediments Forming the Unconfined Aquifer 
Area calculations were made using the ArcInfo geographic information system. Volume calculations were performed using a three-dimensional model of the Hanford geology in Earth Vision software. The plume outlines were draped onto the water table, and the software calculated the volume of saturated sediment between that and the basalt. Minor differences may exist between the geologic model developed in Earth Vision and the depictions of the geologic surfaces derived from ArcInfo data sets and shown in the figures in this report. The average aquifer thickness for each plume area, calculated by Earth Vision, is included in the summary tables. The calculated volumes are based on the aquifer bounded on the bottom by the basalt surface used for the Groundwater Data Package for Hanford Assessments (Thorne et al. 2006). The volumes for the specified contaminant contours are based on the modeled aquifer thickness, which may vary over the volume of the contour area, and therefore, do not necessarily correspond to the thickness of water in an individual well or a group of wells. New well data in the 200-BP-5 area indicate that the basalt surface from the Groundwater Data Package for Hanford Assessments (Thorne et al. 2006) may be different by up to several meters in the this area.

There is evidence that there is direct connection between the Rattlesnake Ridge interbed and the unconfined aquifer in an area north of the northwest corner of the 200-East Area. This erosional window through the basalt is an area of discharge from the interbed to the unconfined aquifer, so the base of the Hanford formation sediments are used to estimate the depth of contaminated aquifer.

The following sections define the conceptual model for each COC. Based on this information, the areal extent of treatment for each COC is shown in Table 2.1. Note that these are not the exact areal extent shown for each COC but are a selected set of areas for use in estimating the scale of treatment relevant to plume elements. The impact of treating a selected volume in terms of meeting the overall remediation goals was not assessed as part of the screening evaluation. The fate and transport evaluation necessary to assess the impact to the overall remediation goal will be conducted as part of the subsequent feasibility study.

Table 2.1. Areal Extent Considered in Screening for each Contaminant of Concern

\begin{tabular}{||l|c||}
\hline \hline \multicolumn{1}{|c|}{$\begin{array}{c}\text { Contaminant of } \\
\text { Concern }\end{array}$} & $\begin{array}{c}\text { Areal Extent Considered } \\
\text { in Screening (acre) }\end{array}$ \\
\hline \hline Chromium & 1,5 (selected, no data available) \\
\hline Technetium-99 & $1,5,25,250,>250$ \\
\hline Iodine-129 & $1,5,>250$ \\
\hline Uranium & $1,5,25$ \\
\hline Plutonium & 1 \\
\hline Nitrate & $1,5,25,250,>250$ \\
\hline Cyanide & 25 \\
\hline Tritium & $1,5,25$ \\
\hline
\end{tabular}

\subsection{Technetium-99}

Technetium-99 in the 200-BP-5 Operable Unit is found at levels above the drinking water standard in a plume extending from the vicinity of the BY cribs and B-BX-BY tank farms to the northwest (Figure 2.4). Northwest of the 200-East Area the contour locations are uncertain due to sparse well coverage. The highest concentrations, greater than $9,000 \mathrm{pCi} / \mathrm{L}$, are restricted to the immediate area of 
the BY cribs. A second plume of technetium-99 is restricted to the area of the C Tank Farm. The technetium-99 contamination in several wells near the C Tank Farm has increased considerably in the past decade indicating a continuing source from the vadose zone.

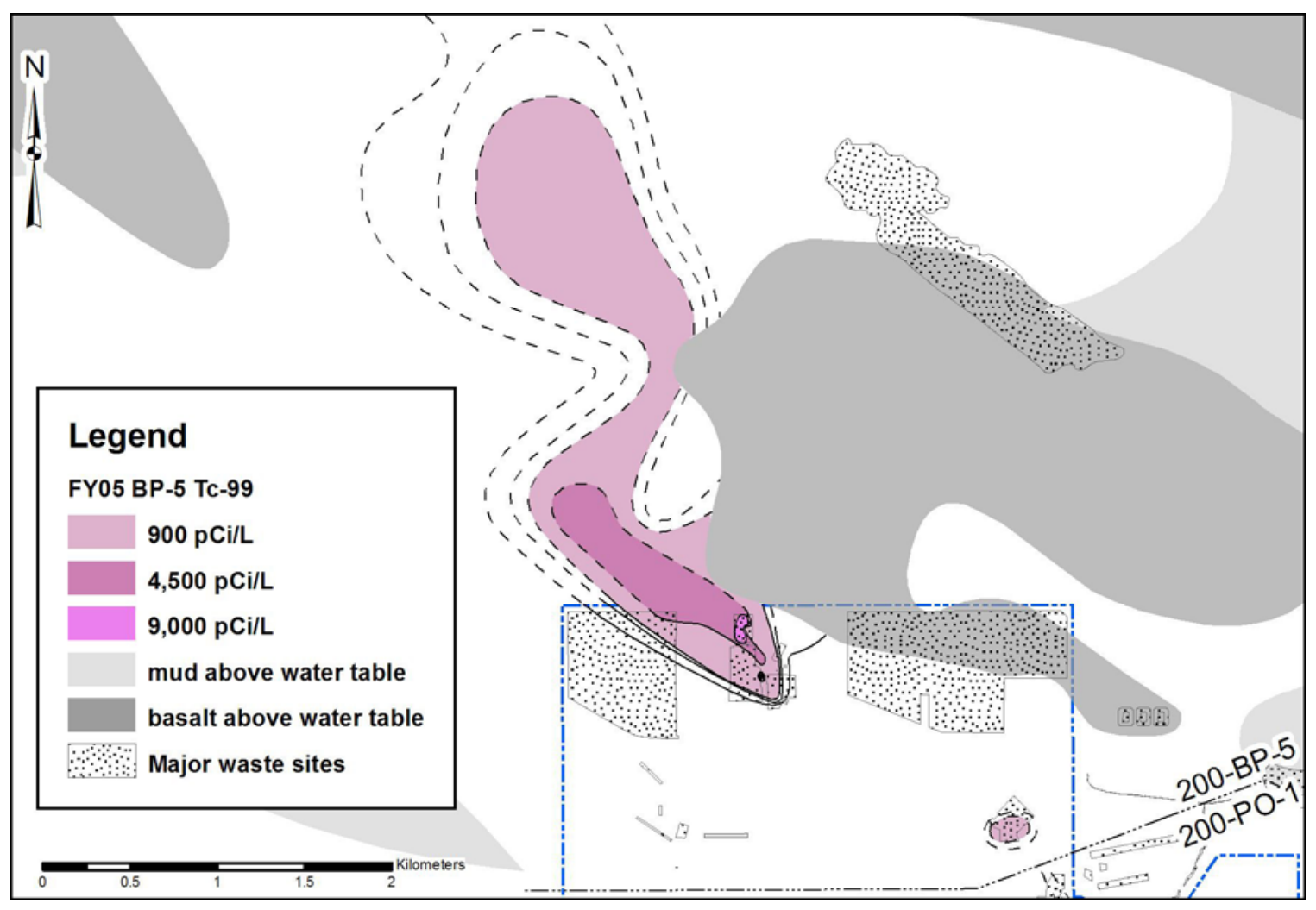

Figure 2.4. Average Technetium-99 Concentrations in 200-East Area, Top of Unconfined Aquifer

The area and volume calculations for the technetium-99 contamination are summarized in Table 2.2.

Table 2.2. Area and Volume of Technetium-99 Contamination for Remediation Technology Screening

\begin{tabular}{||c|c|c|c|c||}
\hline \hline \multirow{2}{*}{ Area } & $\begin{array}{c}\text { Concentration } \\
(\mathrm{pCi} / \mathrm{L})\end{array}$ & $\begin{array}{c}\text { Area } \\
\mathrm{m}^{2}(\mathrm{acre})\end{array}$ & $\begin{array}{c}\text { Average Thickness } \\
(\mathrm{m})\end{array}$ & $\begin{array}{c}\text { Aquifer Volume } \\
\left(\mathrm{m}^{3}\right)\end{array}$ \\
\hline \hline \multirow{3}{*}{ BY Cribs } & 900 & $2,141,992(529)$ & 9.5 & $20,079,746$ \\
\cline { 2 - 5 } & 4,500 & $369,928(91)$ & 1.4 & 515,694 \\
\cline { 2 - 5 } & 9,000 & $8,612(2)$ & 0.7 & 6,084 \\
\hline \multirow{2}{*}{ WMA C } & 900 & $26,337(7)$ & 14.2 & 374,803 \\
\hline \multirow{3}{*}{ Total } & $\mathbf{9 0 0}$ & $\mathbf{2 , 1 6 8 , 3 2 9}$ & -- & $\mathbf{2 0 , 4 5 4 , 5 4 9}$ \\
\cline { 2 - 6 } & $\mathbf{4 , 5 0 0}$ & $\mathbf{3 6 9 , 9 2 8}$ & -- & $\mathbf{5 1 5 , 6 9 4}$ \\
\cline { 2 - 6 } & $\mathbf{9 , 0 0 0}$ & $\mathbf{8 , 6 1 2}$ & -- & $\mathbf{6 , 0 8 4}$ \\
\hline
\end{tabular}




\subsection{Iodine-129}

Iodine-129 at levels above the drinking water standard forms a broad northwest-southeast trending band through the 200-East Area (Figure 2.5). The contamination extends into the 200-PO-1 Operable Unit to the south. The iodine-129 contamination also extends to the east and is found in the confined or semi-confined aquifer below the Ringold Formation mud in the vicinity of the former B Pond. Only one well in the 200-BP-5 Operable Unit had an iodine-129 level above 5 pCi/L in fiscal year 2005, although wells in the 200-PO-1 Operable Unit also had concentrations above $5 \mathrm{pCi} / \mathrm{L}$. In recent years, other 200-BP-5 wells also showed iodine-129 greater than 5 pCi/L.

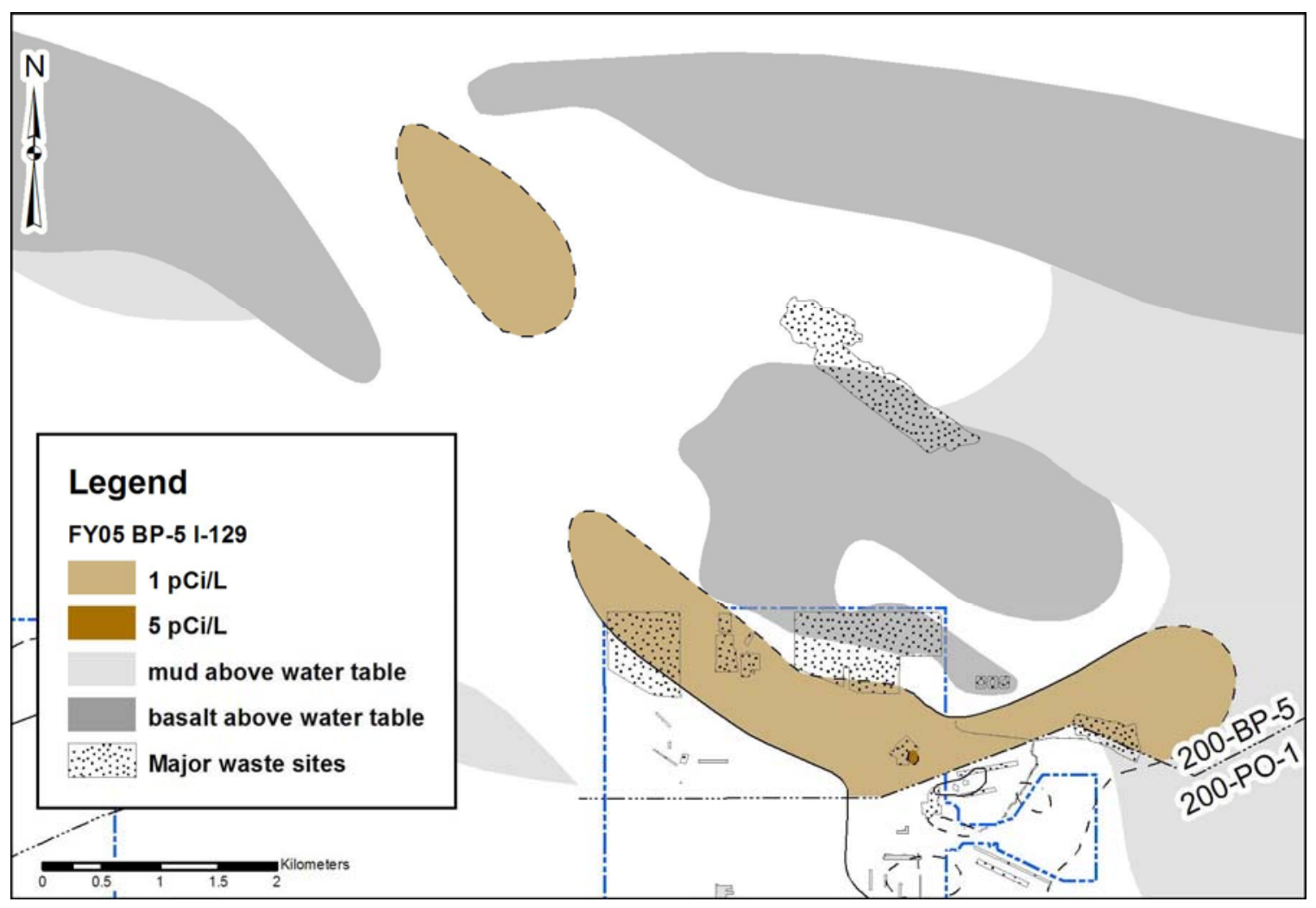

Figure 2.5. Average Iodine-129 Concentrations in 200-East Area, Top of Unconfined Aquifer

The broad, diffuse iodine-129 plume suggests multiple contaminant sources. Some of the contamination likely came from the Plutonium-Uranium Extraction (PUREX) cribs in the 200-PO-1 Operable Unit. Discharges to B Pond are another possible source. The area and volume calculations for the iodine-129 contamination are summarized in Table 2.3. 
Table 2.3. Area and Volume of Iodine-129 Contamination for Remediation Technology Screening

\begin{tabular}{||l|c|c|c|c||}
\hline \hline \multicolumn{1}{|c|}{ Area } & $\begin{array}{c}\text { Concentration } \\
(\mathrm{pCi} / \mathrm{L})\end{array}$ & $\begin{array}{c}\text { Area } \\
\mathrm{m}^{2}(\mathrm{acre})\end{array}$ & $\begin{array}{c}\text { Average Thickness } \\
(\mathrm{m})\end{array}$ & $\begin{array}{c}\text { Aquifer Volume } \\
\left(\mathrm{m}^{3}\right)\end{array}$ \\
\cline { 2 - 6 } & 1 & $4,439,510(1097)$ & 6.5 & $28,724,847$ \\
\hline \hline 200-East & 5 & $8,480(2)$ & 13.8 & 117,098 \\
\hline \multirow{2}{*}{ Total } & 1 & $1,601,101(396)$ & 26.8 & $42,996,600$ \\
\cline { 2 - 6 } & $\mathbf{1}$ & $\mathbf{6 , 0 4 0 , 6 1 1}$ & -- & $\mathbf{7 1 , 7 2 1 , 4 4 7}$ \\
\cline { 2 - 6 } & $\mathbf{5}$ & $\mathbf{8 , 4 8 0}$ & -- & $\mathbf{1 1 7 , 0 9 8}$ \\
\hline
\end{tabular}

\subsection{Uranium}

Uranium is found in a northwest-southeast trending plume near the B-BX-BY tank farms and extending beyond the 200-East Area boundary (Figure 2.6). The northern side of the plume is not clearly defined by the current well coverage. Tank BX-102 is a likely source of much of the uranium contamination, although other sources have not been completely ruled out as additional contributors. The uranium maps in Hartman et al. (2006) used 30, 60, 90, and $500 \mu \mathrm{g} / \mathrm{L}$ contours. The $60 \mu \mathrm{g} / \mathrm{L}$ contour was not needed for the screening, but a $250 \mu \mathrm{g} / \mathrm{L}$ contour was added because the 90 and $500 \mu \mathrm{g} / \mathrm{L}$ did not adequately represent the extent of the relatively high concentrations.

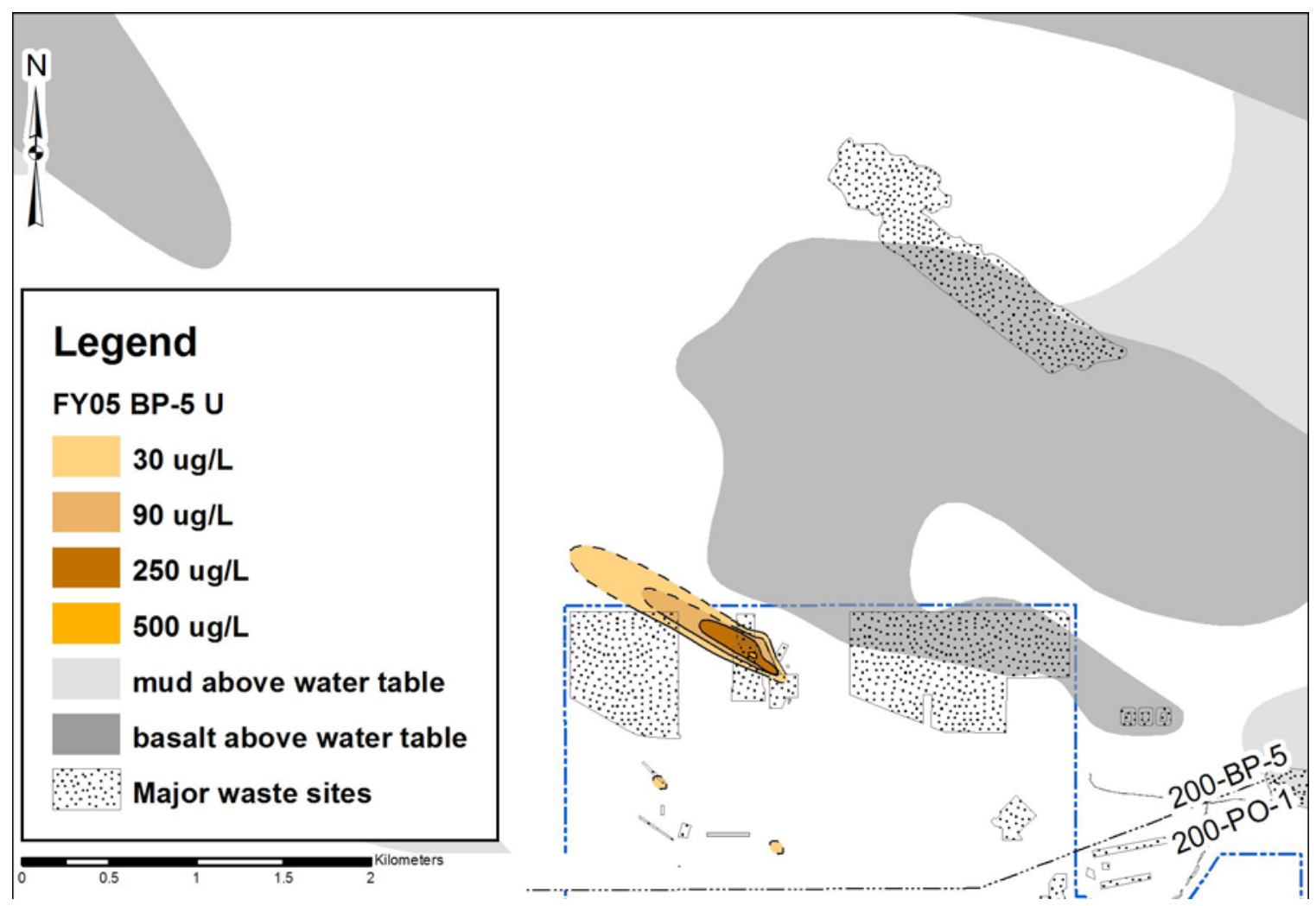

Figure 2.6. Average Uranium Concentrations in 200-East Area, Top of Unconfined Aquifer 
Two small areas of uranium contamination at levels above the drinking water standard are shown in the southern part of 200-BP-5. One is located south of the 216-B-5 injection well. The other is located near the 216-B-62 crib, although the 216-B-12 crib is another possible source for the uranium contamination. The area and volume calculations for the uranium contamination are summarized in Table 2.4.

Table 2.4. Area and Volume of Uranium Contamination for Remediation Technology Screening

\begin{tabular}{||c|c|c|c|c||}
\hline \hline \multirow{4}{*}{ Area } & $\begin{array}{c}\text { Concentration } \\
(\mu \mathrm{g} / \mathrm{L})\end{array}$ & $\begin{array}{c}\text { Area } \\
\mathrm{m}^{2}(\mathrm{acre})\end{array}$ & $\begin{array}{c}\text { Average Thickness } \\
(\mathrm{m})\end{array}$ & $\begin{array}{c}\text { Aquifer Volume } \\
\left(\mathrm{m}^{3}\right)\end{array}$ \\
\hline \hline \multirow{3}{*}{ B-BX-BY } & 30 & $289,439(72)$ & 1.5 & 429,970 \\
\cline { 2 - 5 } & 90 & $114,423(28)$ & 1.2 & 131,305 \\
\cline { 2 - 5 } & 250 & $43,465(11)$ & 1.0 & 43,465 \\
\cline { 2 - 5 } & 500 & $1,139(0.3)$ & 1.3 & 1,431 \\
\hline 216-B-5 & 30 & $4,752(1)$ & 22.9 & 108,591 \\
\hline 216-B-62 & 30 & $4,748(1)$ & 14.5 & $\mathbf{6 0 7 , 4 2 2}$ \\
\hline \multirow{3}{*}{ Total } & $\mathbf{3 0}$ & $\mathbf{2 9 8 , 9 3 9}$ & -- & $\mathbf{1 3 1 , 3 0 5}$ \\
\cline { 2 - 5 } & $\mathbf{9 0}$ & $\mathbf{1 1 4 , 4 2 3}$ & -- & $\mathbf{4 3 , 4 6 5}$ \\
\cline { 2 - 6 } & $\mathbf{2 5 0}$ & $\mathbf{4 3 , 4 6 5}$ & -- & $\mathbf{1 , 4 3 1}$ \\
\cline { 2 - 6 } & $\mathbf{5 0 0}$ & $\mathbf{1 , 1 3 9}$ & -- & \\
\hline
\end{tabular}

\subsection{Plutonium and Cesium-137}

Plutonium is only detected in three wells in the 200-BP-5 Operable Unit. These wells are located in the immediate vicinity of the 216-B-5 injection well. The detected concentrations of plutonium-239/ plutonium-240 ranged from 1.45 to $19.4 \mathrm{pCi} / \mathrm{L}$ in unfiltered samples. Plutonium is not addressed in the EPA drinking water standards. The draft 200-BP-5 remedial investigation/feasibility study data quality objective lists an action level of $1.2 \mathrm{pCi} / \mathrm{L}$, which was used for the screening evaluation. Given the restricted number of wells with detected plutonium and plutonium's known low mobility in groundwater, the volume calculations are depicted conservatively as being based on the 1,000 pCi/L strontium-90 contour (Table 2.5). Plutonium at 216-B-5 was detected in sediments throughout the aquifer above basalt (Smith 1980), although the highest concentrations were near the water table elevation from the operational period. Thus, the entire aquifer thickness was used in the screening calculations.

Cesium-137 is also only detected in the same three wells as plutonium in the 200-BP-5 Operable Unit. Only one well had levels above the $200-\mathrm{pCi} / \mathrm{L}$ drinking water standard; the values in the three wells ranged from 44.3 to $663 \mathrm{pCi} / \mathrm{L}$. Thus, the volume calculations based on the $1,000 \mathrm{pCi} / \mathrm{L}$ strontium-90 contour are considered to be conservative and adequate for screening purposes. Cesium-137 was also detected throughout the entire aquifer thickness above basalt (Smith 1980). 
Table 2.5. Area and Volume of Plutonium and Cesium-137 Contamination for Remediation Technology Screening

\begin{tabular}{||l|c|c|c|c||}
\hline \multicolumn{1}{|c|}{ Area } & $\begin{array}{c}\text { Concentration } \\
(\mathrm{pCi} / \mathrm{L} \text { Pu-240/Cs-137) }\end{array}$ & $\begin{array}{c}\text { Area } \\
\mathrm{m}^{2}(\text { acre })\end{array}$ & $\begin{array}{c}\text { Average Thickness } \\
(\mathrm{m})\end{array}$ & $\begin{array}{c}\text { Aquifer Volume } \\
\left(\mathrm{m}^{3}\right)\end{array}$ \\
\hline \hline 216-B-5 & $1.2 / 200$ & $564(0.1)$ & 12.2 & 6,894 \\
\hline Total & $\mathbf{1 . 2 / 2 0 0}$ & $\mathbf{5 6 4}$ & -- & $\mathbf{6 , 8 9 4}$ \\
\hline
\end{tabular}

\subsection{Nitrate}

Nitrate contamination is widespread in the 200-BP-5 Operable Unit (Figure 2.7). The largest plume appears to be a combination of contamination from the 200-PO-1 Operable Unit merging with contamination from the vicinity of the BY cribs, the B-BX-BY tank farms, and other nearby sources. The highest concentrations are found near the BY and other cribs in the northern part of the 200-East Area. Smaller nitrate plumes are seen near the former Gable Mountain Pond, near the Low-Level Waste Management Area 2 (LLWMA-2), and near the C Tank Farm. The area and volume calculations for the nitrate contamination are summarized in Table 2.6.

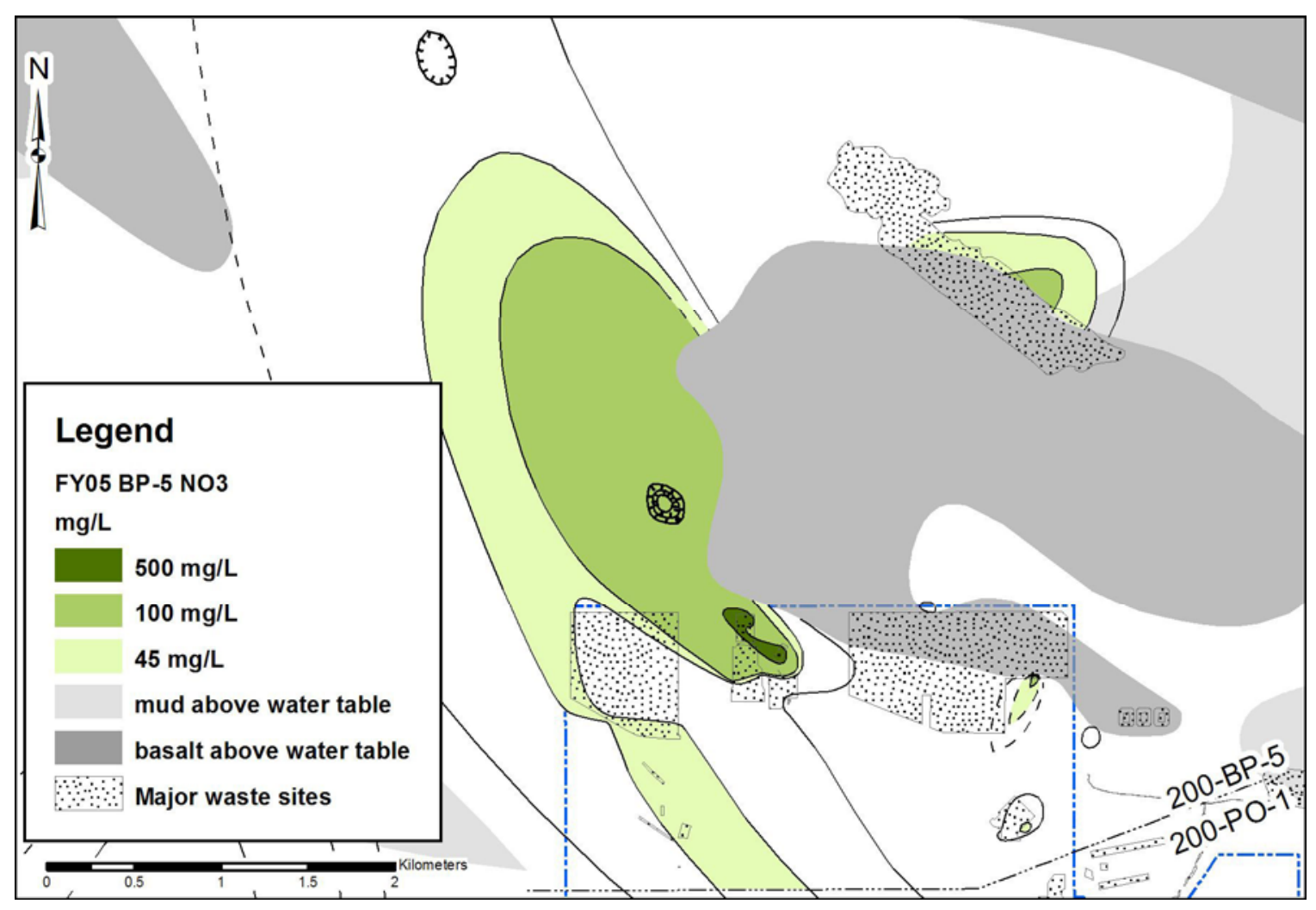

Figure 2.7. Average Nitrate Concentrations in 200-East Area, Top of Unconfined Aquifer 
Table 2.6. Area and Volume of Nitrate Contamination for Remediation Technology Screening

\begin{tabular}{||l|c|c|c|c||}
\hline \multirow{3}{*}{ Area } & $\begin{array}{c}\text { Concentration } \\
(\mathrm{mg} / \mathrm{L})\end{array}$ & $\begin{array}{c}\text { Area } \\
\mathrm{m}^{2}(\mathrm{acre})\end{array}$ & $\begin{array}{c}\text { Average Thickness } \\
(\mathrm{m})\end{array}$ & $\begin{array}{c}\text { Aquifer Volume } \\
\left(\mathrm{m}^{3}\right)\end{array}$ \\
\hline \hline \multirow{3}{*}{ BY cribs Area } & 45 & $4,383,049(1,083)$ & 8.1 & $34,019,210$ \\
\cline { 2 - 5 } & 100 & $2,239,483(553)$ & 7.8 & $16,192,335$ \\
\cline { 2 - 5 } & 500 & $36,616(9)$ & 1.1 & 38,479 \\
\hline \multirow{2}{*}{ Gable Mt. Pond } & 45 & $267,290(66)$ & 4.2 & $1,034,350$ \\
\cline { 2 - 6 } & 100 & $38,131(9)$ & 4.5 & 171,127 \\
\hline \multirow{2}{*}{ LLWMA-2 } & 45 & $13,004(3)$ & 0.6 & 8,329 \\
\hline C Tank Farm & 100 & $1,738(0.4)$ & 0.3 & 522 \\
\hline \multirow{2}{*}{ Total } & 45 & $2,501(0.6)$ & 13.5 & 33,854 \\
\cline { 2 - 6 } & $\mathbf{4 5}$ & $\mathbf{4 , 6 6 5 , 8 4 4}$ & -- & $\mathbf{3 5 , 0 9 5 , 7 4 3}$ \\
\cline { 2 - 6 } & $\mathbf{1 0 0}$ & $\mathbf{2 , 2 7 9 , 3 5 2}$ & -- & $\mathbf{1 6 , 3 6 3 , 9 8 4}$ \\
\hline
\end{tabular}

\subsection{Cyanide}

The extent of cyanide contamination has not been mapped in recent annual groundwater reports. The highest concentrations of cyanide are typically found near the BY cribs. Uranium recovery waste discharged to these cribs is presumed to be a major source of cyanide in the groundwater. Interpretation of the extent of cyanide contamination is complicated by the high variability seen with time in analyses from individual wells. The reason for the high variability has not been determined but may be induced by uncertainties in the analytical method. There is also considerable uncertainty in the extent due to sparse well coverage north of the 200-East Area. The approximate extent of cyanide contamination at levels above the $100 \mu \mathrm{g} / \mathrm{L}$ drinking water standard, based on an interpretation of the fiscal year 2005 data, is shown in Figure 2.8. The area and volumes of cyanide contamination are summarized in Table 2.7.

\subsection{Tritium}

Tritium levels are less than the drinking water standard through most of the 200-BP-5 Operable Unit (Figure 2.9). However, tritium is found at levels above the drinking water standard in Gable Gap, beneath the mud unit at the former B Pond, in a single well at the BY cribs, and near the southern boundary of the operable unit. The area and volume calculations for the tritium contamination are summarized in Table 2.8.

\subsection{Cobalt-60}

Cobalt-60 was only detected at levels above the 100 -pCi/L drinking water standard in one well in the 200-BP-5 Operable Unit. This well, 299-E33-4, is located in the northeastern BY cribs. It should be noted that the well contains only approximately $0.4 \mathrm{~m}$ of water above the top of the perforated interval, and the perforations reach the top of basalt. Thus, it is only sampling the uppermost part of the unconfined aquifer and may not be representative of concentrations throughout the aquifer. Other nearby wells have cobalt-60 concentrations less than the drinking water standard (e.g., well 299-E33-7 contained 
$\sim 55 \mathrm{pCi} / \mathrm{L}$ in recent samples, and well 299-E33-38 contained $\sim 40 \mathrm{pCi} / \mathrm{L}$ in recent samples). Well 299-E33-7 is approximately $40 \mathrm{~m}$ from well 299-E33-4 so the area with concentrations greater than the drinking water standard will be estimated as a circle with a 20 -m radius. The depth of contamination will be approximated as $1 \mathrm{~m}$. The area and volumes of cobalt-60 contamination are summarized in Table 2.9. Cobalt-60 has a relatively short half life of 5.27 years.

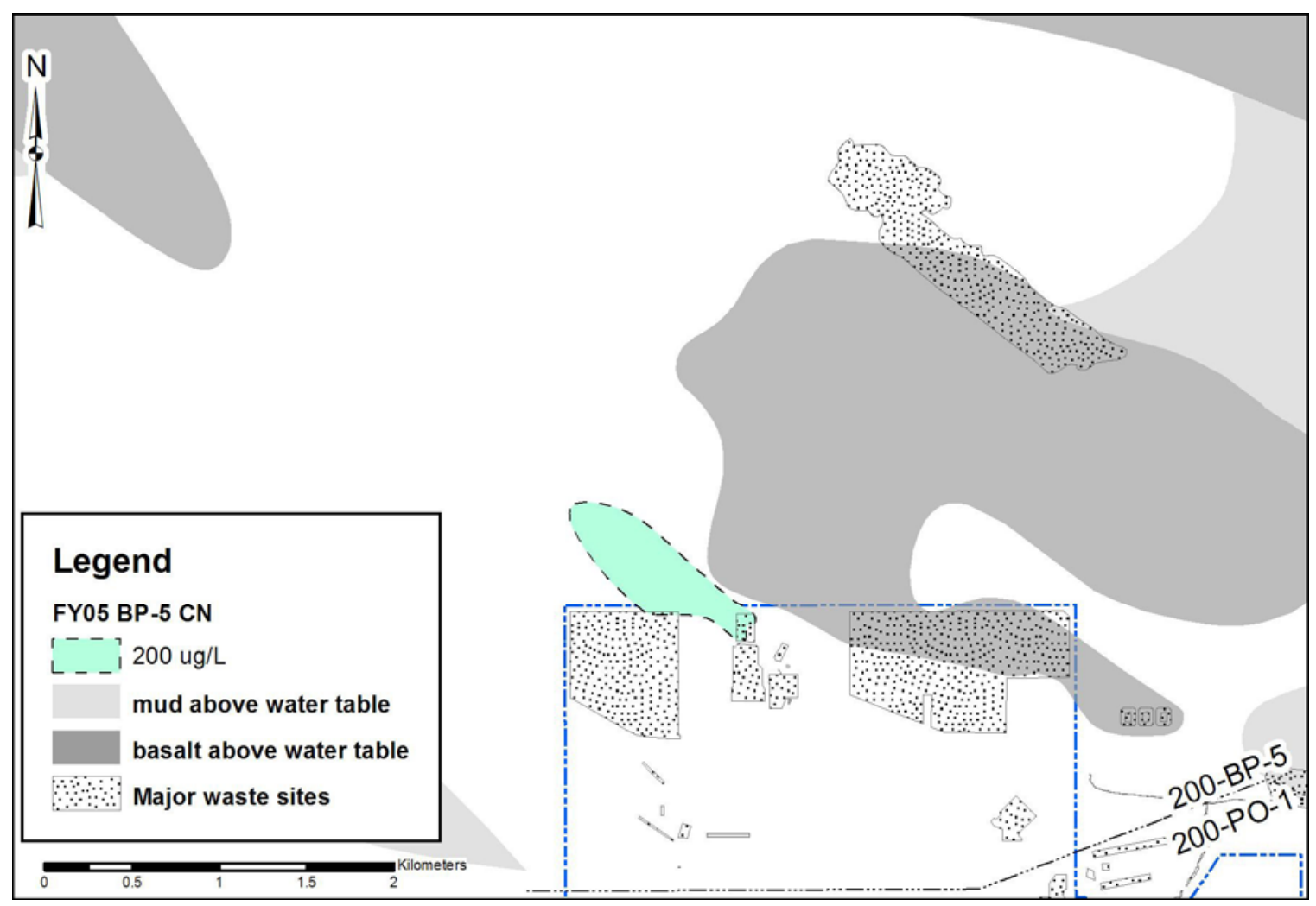

Figure 2.8. Average Cyanide Concentrations in 200-East Area, Top of Unconfined Aquifer

Table 2.7. Area and Volume of Cyanide Contamination for Remediation Technology Screening

\begin{tabular}{||l|c|c|c|c||}
\hline \multicolumn{1}{|c|}{ Area } & $\begin{array}{c}\text { Concentration } \\
(\mu \mathrm{g} / \mathrm{L})\end{array}$ & $\begin{array}{c}\text { Area } \\
\mathrm{m}^{2}(\mathrm{acre})\end{array}$ & $\begin{array}{c}\text { Average Thickness } \\
(\mathrm{m})\end{array}$ & $\begin{array}{c}\text { Aquifer Volume } \\
\left(\mathrm{m}^{3}\right)\end{array}$ \\
\hline \hline 216-B-5 & 100 & $348,804(86)$ & 1.4 & 485,917 \\
\hline Total & $\mathbf{1 0 0}$ & $\mathbf{3 4 8 , 8 0 4}$ & -- & $\mathbf{4 8 5 , 9 1 7}$ \\
\hline
\end{tabular}




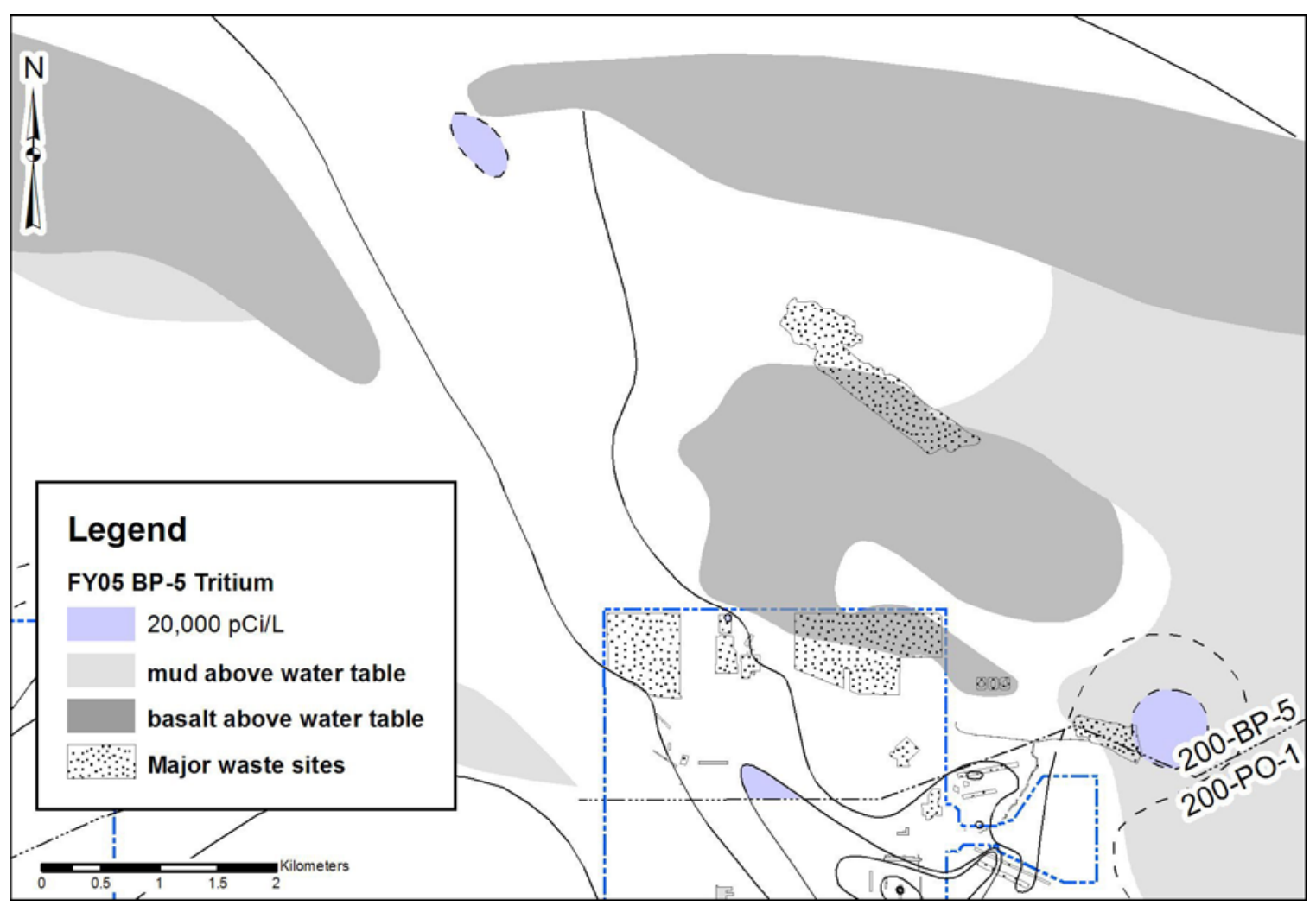

Figure 2.9. Average Tritium Concentrations in 200-East Area, Top of Unconfined Aquifer

Table 2.8. Area and Volume of Tritium Contamination for Remediation Technology Screening

\begin{tabular}{||l|c|c|c|c||}
\hline \multicolumn{1}{|c|}{ Area } & $\begin{array}{c}\text { Concentration } \\
(\mathrm{mg} / \mathrm{L})\end{array}$ & $\begin{array}{c}\text { Area } \\
\mathrm{m}^{2}(\mathrm{acre})\end{array}$ & $\begin{array}{c}\text { Average Thickness } \\
(\mathrm{m})\end{array}$ & $\begin{array}{c}\text { Aquifer Volume } \\
\left(\mathrm{m}^{3}\right)\end{array}$ \\
\hline \hline Gable Gap & 20,000 & $161,347(40)$ & 19.2 & $3,089,021$ \\
\hline B Pond & 20,000 & $352,785(87)$ & 11.4 & $4,005,324$ \\
\hline Southern Area & 20,000 & $89,639(22)$ & 24.8 & $2,216,993$ \\
\hline BY Cribs & 20,000 & $2,678(0.7)$ & 0.9 & 2,435 \\
\hline Total & $\mathbf{2 0 , 0 0 0}$ & $\mathbf{6 0 6 , 4 4 9}$ & -- & $\mathbf{9 , 3 1 3 , 7 7 3}$ \\
\hline \hline
\end{tabular}

Table 2.9. Area and Volume of Cobalt-60 Contamination

\begin{tabular}{||l|c|c|c|c||}
\hline \multicolumn{1}{|c|}{ Area } & $\begin{array}{c}\text { Concentration } \\
(\mathrm{pCi} / \mathrm{L})\end{array}$ & $\begin{array}{c}\text { Area } \\
\mathrm{m}^{2}(\mathrm{acre})\end{array}$ & $\begin{array}{c}\text { Average Thickness } \\
(\mathrm{m})\end{array}$ & $\begin{array}{c}\text { Aquifer Volume } \\
\left(\mathrm{m}^{3}\right)\end{array}$ \\
\hline \hline 216-BY cribs & 100 & $1,257(0.3)$ & 1 & 1,257 \\
\hline Total & $\mathbf{1 0 0}$ & $\mathbf{1 , 2 5 7}$ & -- & $\mathbf{1 , 2 5 7}$ \\
\hline
\end{tabular}




\subsection{Strontium-90}

Strontium-90 is found at levels above the drinking water standard near the former Gable Mountain Pond and at the 216-B-5 injection well (Figure 2.10). The contamination at Gable Mountain Pond is in a very thin part of the aquifer, and part of the contamination may be present in fractured basalt at the contact with the sediments. Some contamination may also be present in the Ringold mud units. The contamination at the 216-B-5 injection well is associated with localized uranium, cesium-137, and plutonium contamination. The area and volume calculations for the strontium-90 contamination are summarized in Table 2.10.

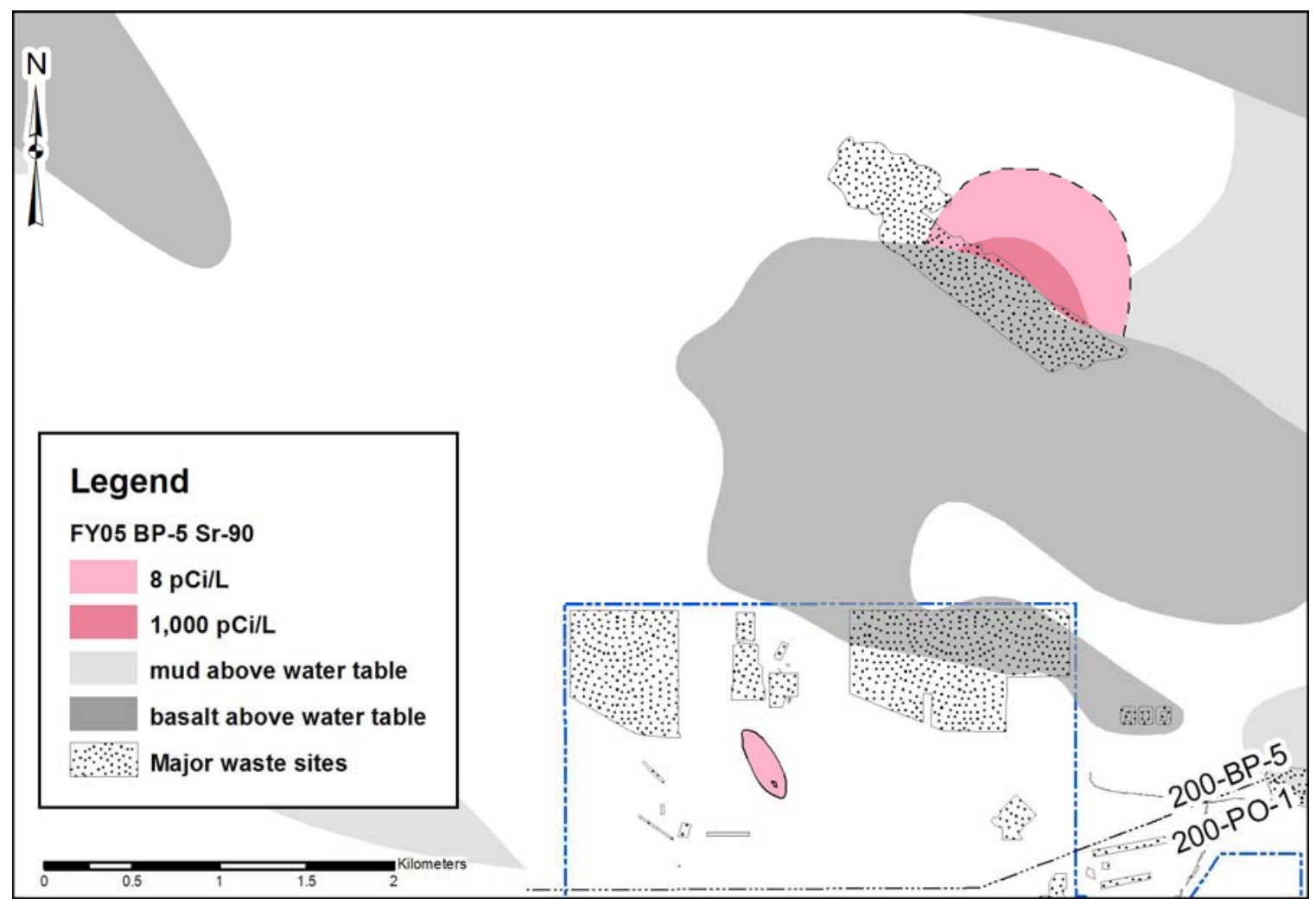

Figure 2.10. Average Strontium-90 Concentrations in 200-East Area, Top of Unconfined Aquifer

Table 2.10. Area and Volume of Strontium-90 Contamination

\begin{tabular}{||l|c|c|c|c||}
\hline \hline \multirow{2}{*}{ Area } & $\begin{array}{c}\text { Concentration } \\
(\mathrm{pCi} / \mathrm{L})\end{array}$ & $\begin{array}{c}\text { Area } \\
\mathrm{m}^{2}(\mathrm{acre})\end{array}$ & $\begin{array}{c}\text { Average Thickness } \\
(\mathrm{m})\end{array}$ & $\begin{array}{c}\text { Aquifer Volume } \\
\left(\mathrm{m}^{3}\right)\end{array}$ \\
\hline \hline \multirow{2}{*}{ 216-B-5 } & 8 & $53,931(13)$ & 9.8 & 526,868 \\
\cline { 2 - 5 } & 1,000 & $564(0.1)$ & 12.2 & 6,894 \\
\hline \multirow{2}{*}{$\begin{array}{l}\text { Gable Mt. } \\
\text { Pond }\end{array}$} & 8 & $662,905(164)$ & 5.2 & $3,171,619$ \\
\cline { 2 - 6 } Total & 1,000 & $136,965(34)$ & 4.5 & 608,064 \\
\cline { 2 - 6 } & $\mathbf{8}$ & $\mathbf{7 1 6 , 8 3 6}$ & -- & $\mathbf{3 , 6 9 8 , 4 8 7}$ \\
\hline
\end{tabular}




\subsection{Remediation Objectives}

The remediation goals for this screening evaluation are the drinking water criteria identified in the Groundwater Sampling and Analysis Plan for 200-BP-5 OU (DOE/RL-2001-49, Rev. 1). Hexavalent chromium is also added for consideration with a target of the drinking water standard due to presence of significant inventories in waste sites where groundwater has not been monitored to date. The goals are:

- Hexavalent chromium $(100 \mu \mathrm{g} / \mathrm{L})$

- Technetium-99 (900 pCi/L)

- Iodine-129 (1 pCi/L)

- Uranium (30 $\mu \mathrm{g} / \mathrm{L})$

- Plutonium-239/240 (1.2 pCi/L)

- Nitrate (45 mg/L as $\mathrm{NO}_{3}$ )

- Cyanide (100 $\mu \mathrm{g} / \mathrm{L})$

- $\operatorname{Tritium}(20,000 \mathrm{pCi} / \mathrm{L})$ 


\subsection{Assumptions}

The following assumptions were used as part of conducting the screening evaluation:

- Contaminant distribution was based on current data for groundwater contamination. The potential for continuing contamination flux from the vadose zone was not explicitly considered. However, the screening included assessment of remediation methods potentially suitable for application to a small continuing source area in the groundwater.

- The screening evaluation considered application of remediation methods to specific treatment volumes, but did not estimate the timeframe for treatment. Thus, the relative cost and effectiveness assessments were based on factors other than the treatment timeframe.

- The screening evaluation was conducted using the data available and the general conceptual model presented in this report. Uncertainty in the data and conceptual model was not addressed. Instead, the evaluation assessed potential remediation methods based on application to a specified treatment volume.

- The general conceptual model used for the screening evaluation was intended to describe the volume and extent of the plume suitably for use in screening potential remediation methods. The conceptual model did not include all aspects important for defining the fate and transport of a contaminant. The evaluation assessed potential remediation methods based on application to a specified treatment volume.

- Analysis was limited to contamination in the supra-basalt aquifer system. 


\subsection{Evaluation Criteria}

The screening evaluation was conducted in two primary steps. The initial screening step evaluated potential remediation methods based on whether they can be effectively applied within the environmental setting of the 200-BP-5 Operable Unit for the specified contaminants. In the second step, potential remediation methods were screened using scoping calculations to estimate the scale of infrastructure, overall quantities of reagents, and conceptual approach for applying the method for each defined grouping of COC. Based on these estimates, each method was screened with respect to effectiveness, implementability, and relative cost categories of the CERCLA feasibility study screening process defined in the EPA guidance (EPA 1988). In general, the effectiveness evaluation is related to 1) the estimated reliability of the process and whether it has been proven successful, 2) the expected ability of the method to treat the necessary volume of contaminated media, and 3) the ability to be constructed and operated without negative human or environmental impacts. Implementability is generally related to 1 ) the scale of effort and technical certainty that the method can be implemented at the site; 2) the availability of consumables, equipment, and services; and 3) the ability to obtain permits and administratively manage the method. The relative cost is generally evaluated using a general conceptual design and relative cost estimates based on the relative capital and operation and maintenance required for each option.

The specific evaluation criteria for each of these screening categories are listed in Table 5.1. Remediation methods were eliminated from further consideration based on a comparative assessment of implementability, effectiveness, and relative cost, whereby those methods with significant uncertainty in effectiveness, significant difficulties for implementation, and relatively high costs compared to other more viable and less costly methods were identified and screened out. Innovative methods were assessed based on the available information in the literature. It may be necessary to conduct treatability studies as part of final assessment and implementation for some innovative methods. Presumptive remedies applicable within the environmental setting were retained for use in the more detailed analysis of remediation alternatives that will be conducted as part of the full feasibility study. 
Table 5.1. Screening Evaluation Criteria for the Second Step of Screening

\begin{tabular}{|c|c|c|}
\hline Effectiveness & Implementability & Relative Cost \\
\hline $\begin{array}{l}\text { - Is the method able to reliably decrease } \\
\text { contaminant concentration, mass, or } \\
\text { mobility to meet 1) the target concentration } \\
\text { or 2) ten times the target concentration? } \\
\text { Does the method produce no hazardous } \\
\text { products unless these are readily } \\
\text { remediated or attenuated? } \\
\text { Does the method negatively impact the } \\
\text { remediation of other COC to the extent that } \\
\text { the remediation objectives could not be } \\
\text { met for the other COC? } \\
\text { For the plume thicknesses identified in the } \\
\text { conceptual model, is the method suitable } \\
\text { for decreasing contaminant concentration, } \\
\text { mass, or mobility of } 1 \text { ) continuing source } \\
\text { in groundwater with an areal extent of less } \\
\text { than } 1 \text { acre, } 2 \text { ) high concentrations within } \\
\text { an areal extent of less than } 5 \text { acres, } 3 \text { ) high } \\
\text { or low concentrations within an areal } \\
\text { extent of up to } 25 \text { acres, and } 4 \text { ) low con- } \\
\text { centrations for an areal extent of } 250 \text { acres } \\
\text { or greater than } 250 \text { acres? The volume of } \\
\text { treatment for these targets will be defined } \\
\text { based on the depth of the individual COC. } \\
\text { Does the method cause significant human } \\
\text { or environmental risk during construction } \\
\text { or operation? }\end{array}$ & $\begin{array}{l}\text { Can the method be } \\
\text { reliably constructed and } \\
\text { operated for the target } \\
\text { volume (see effectiveness } \\
\text { categories) within the } \\
\text { Hanford aquifer } \\
\text { (technical uncertainty at } \\
\text { scale of application)? } \\
\text { Can the consumable or } \\
\text { reagent usage be } \\
\text { reasonably provided at } \\
\text { the scale of application? }\end{array}$ & $\begin{array}{l}\text { Based on scoping } \\
\text { calculations defining the } \\
\text { scale of infrastructure and } \\
\text { consumables, are the } \\
\text { relative costs for capital } \\
\text { and operation/maintenance } \\
\text { expected to be grossly } \\
\text { higher than for other } \\
\text { options with similar } \\
\text { effectiveness and } \\
\text { implementability? }\end{array}$ \\
\hline
\end{tabular}




\subsection{Potential Remediation Methods}

The potential remediation methods for each COC grouping are shown in Tables 6.1 through 6.3. The potential remediation methods were identified from a review of EPA resources and technical literature including the http://www.epareachit.org and http://www.frtr.gov technology information websites. The screening focuses on categories of remediation method, not specific commercial products, unless there is only one commercial vendor for a remediation method category. Potential methods only demonstrated at the laboratory scale were not considered unless there are current efforts to obtain information from field treatability tests.

Table 6.1. Potential Remediation Methods for COC Group 1 (chromium, technetium-99, iodine-129, uranium, and plutonium-239/240)

\begin{tabular}{|c|c|}
\hline General Category & Remediation Method Category \\
\hline No Action & No Action \\
\hline Institutional Controls & Institutional Controls \\
\hline Containment & $\begin{array}{l}\text { Physical Containment } \\
-\quad \text { Slurry Walls } \\
\text { - Grout Curtain } \\
\text { - Sheet Piling } \\
\text { Hydraulic Control } \\
\end{array}$ \\
\hline Removal, treatment, and disposal & Excavation \\
\hline Monitored Natural Attenuation & Monitored Natural Attenuation (MNA) \\
\hline Ex Situ Treatment & $\begin{array}{l}\text { Pump-and-Treat } \\
\text { • Chemical treatment } \\
\text { • } \quad \text { Biological treatment (except I-129 and Pu-239/240) }\end{array}$ \\
\hline \multirow[t]{9}{*}{ In Situ Treatment } & Chemical Stabilization by Apatite (uranium and plutonium) \\
\hline & Chemical Stabilization by Polyphosphate (uranium) \\
\hline & Nanoparticles (other than zero-valent iron) \\
\hline & Down-Well Bio-Reactor/Adsorption Systems \\
\hline & Reduction by Zero-Valent Iron (chromate, uranium isotopes, and Tc-99) \\
\hline & Surfactant Flushing \\
\hline & Phytoremediation \\
\hline & $\begin{array}{l}\text { Anaerobic Bioremediation } \\
\qquad \quad \text { Soluble substrate } \\
-\quad \text { direct reduction (chromate, uranium isotopes and Tc-99) } \\
-\quad \text { Sulfate Reducing Bacteria (chromate, uranium isotopes and Tc-99) } \\
\text { - Injection of long-duration substrate (e.g., a non-aqueous substrate } \\
\text { such as vegetable oil) }\end{array}$ \\
\hline & $\begin{array}{l}\text { Permeable Reactive Barriers } \\
\text { - } \text { Zero-Valent Iron (chromate, uranium isotopes and Tc-99) } \\
\text { - } \text { Apatite barrier (uranium) } \\
\text { - } \text { Adsorosphent barriers } \\
\text { - } \text { Multi-Zone Biobarrier } \\
\text { - } \text { Anaerobic Biobarrier (e.g., injection of long-duration substrate as a } \\
\text { - In Situ Redox Manipulation (chromate, uranium isotopes and Tc-99) }\end{array}$ \\
\hline
\end{tabular}


Table 6.2. Potential Remediation Methods for COC Group 2 (nitrate and cyanide)

\begin{tabular}{|c|c|}
\hline General Category & Remediation Method Category \\
\hline No Action & No Action \\
\hline Institutional Controls & Institutional Controls \\
\hline Containment & $\begin{array}{l}\text { Physical Containment } \\
\text { - } \quad \text { Slurry Walls } \\
\text { - } \quad \text { Grout Curtain } \\
\text { - } \quad \text { Sheet Piling } \\
\text { Hydraulic Control }\end{array}$ \\
\hline Removal, treatment, and disposal & Excavation \\
\hline Monitored Natural Attenuation & Monitored Natural Attenuation (MNA) \\
\hline Ex Situ Treatment & $\begin{array}{l}\text { Pump-and-Treat } \\
\text { - Chemical treatment } \\
\text { o Reduction (nitrate) } \\
\text { o Oxidation (cyanide) } \\
\text { - Biological treatment (nitrate) } \\
\text { - Constructed Wetlands/Phyto-Irrigation }\end{array}$ \\
\hline \multirow[t]{3}{*}{ In Situ Treatment } & Phytoremediation \\
\hline & $\begin{array}{l}\text { Anaerobic Bioremediation (nitrate only) } \\
\text { • } \quad \text { Soluble substrate } \\
\text { • } \quad \text { Injection of long-duration substrate (e.g., a non-aqueous } \\
\\
\text { substrate such as vegetable oil) }\end{array}$ \\
\hline & $\begin{array}{l}\text { Permeable Reactive Barriers (nitrate only) } \\
\bullet \quad \text { Anaerobic Biobarrier (e.g., injection of long-duration } \\
\text { substrate as a barrier) }\end{array}$ \\
\hline
\end{tabular}

Table 6.3. Potential Remediation Methods for COC Group 3 (tritium)

\begin{tabular}{|c|c|}
\hline General Category & Remediation Method Category \\
\hline No Action & No Action \\
\hline Institutional Controls & Institutional Controls \\
\hline Containment & $\begin{array}{cc}\text { Physical Containment } \\
\bullet \quad \text { Slurry Walls } \\
\text { • } \quad \text { Grout Curtain } \\
\text { • } \quad \text { Sheet Piling } \\
\text { Hydraulic Control }\end{array}$ \\
\hline Removal, treatment, and disposal & Excavation \\
\hline Monitored Natural Attenuation & Monitored Natural Attenuation (MNA) \\
\hline Ex Situ Treatment & $\begin{array}{l}\text { Pump-and-Treat } \\
\bullet \quad \text { Isotopic separation }\end{array}$ \\
\hline
\end{tabular}




\subsection{Screening}

Potential remediation methods were screened in a two-step process. Section 7.1 presents the initial screening results. Screening based on scoping calculations is presented in Section 7.2.

\subsection{Initial Screening}

The first step of screening eliminated remediation methods that are infeasible because they are not appropriate for application in the environmental setting of the 200-BP-5 Operable Unit. Tables 7.1 through 7.3 list the remediation method categories screened out in this first stage and the reason they were removed from further consideration.

Table 7.1. COC Group 1 - Remediation Methods Screened Out in Initial Screening

\begin{tabular}{|c|c|}
\hline Remediation Method Category & Reason \\
\hline Containment & $\begin{array}{l}\text { Grout curtains and slurry walls emplaced by trenching and sheet piling are } \\
\text { eliminated due to the depth of the aquifer. Hydraulic control is eliminated as } \\
\text { not applicable for large plumes in transmissive aquifers. Containment by } \\
\text { injectable materials is retained. }\end{array}$ \\
\hline Removal, treatment, and disposal & $\begin{array}{l}\text { Removal, treatment, and disposal technologies are targeted at shallow } \\
\text { contamination only. }\end{array}$ \\
\hline Nanoparticles & $\begin{array}{l}\text { Presently, there are no deployable nanotechnologies other than zero-valent iron } \\
\text { for remediation of the COC. Ongoing studies may result in viable remediation } \\
\text { technologies in the future. }\end{array}$ \\
\hline Phytoremediation & Not appropriate for deep aquifers. \\
\hline Zero-Valent Iron & $\begin{array}{l}\text { Emplacement by trenching is eliminated due to the depth of the aquifer. } \\
\text { Injectable iron is retained as a potential remediation method. }\end{array}$ \\
\hline $\begin{array}{l}\text { Stabilization by Apatite (by } \\
\text { trenching) }\end{array}$ & $\begin{array}{l}\text { Use of solid apatite with emplacement by trenching is eliminated due to the } \\
\text { depth of the aquifer. Use of injectable apatite is retained as a potential } \\
\text { permeable reactive barrier remediation method. }\end{array}$ \\
\hline $\begin{array}{ll}\text { Permeable Reactive Barriers } \\
\text { - } \\
\text { Zero-Valent Iron (by } \\
\text { trenching) } \\
\text { - } \\
\text { - Apatite (by trenching) } \\
\text { - } \quad \text { Multi-Zorbent barriers } \\
\text { - }\end{array}$ & $\begin{array}{l}\text { Use of zero-valent iron, adsorbents, solid apatite or the multi-zone barrier with } \\
\text { emplacement by trenching is eliminated due to the depth of the aquifer. Use of } \\
\text { injectable iron, apatite, or polyphosphate is retained as a potential permeable } \\
\text { reactive barrier remediation method. }\end{array}$ \\
\hline
\end{tabular}

Table 7.2. COC Group 2- Remediation Methods Screened Out in Initial Screening

\begin{tabular}{||l|l||}
\hline \hline Remediation Method Category & \multicolumn{1}{c||}{ Reason } \\
\hline \hline Containment & $\begin{array}{l}\text { Grout curtains and slurry walls emplaced by trenching and sheet piling are } \\
\text { eliminated due to the depth of the aquifer. Hydraulic control is eliminated as } \\
\text { not applicable for large plumes in transmissive aquifers. Containment by } \\
\text { injectable materials is retained. }\end{array}$ \\
\hline Removal, treatment, and disposal & $\begin{array}{l}\text { Removal, treatment, and disposal technologies are targeted at shallow } \\
\text { contamination only }\end{array}$ \\
\hline Phytoremediation & Not appropriate for deep aquifers \\
\hline \hline
\end{tabular}


Table 7.3. COC Group 3 - Remediation Methods Screened Out in Initial Screening

\begin{tabular}{||c|l||}
\hline \hline Remediation Method Category & \multicolumn{1}{|c||}{ Reason } \\
\hline \hline Containment & $\begin{array}{l}\text { Grout curtains and slurry walls emplaced by trenching and sheet piling are } \\
\text { eliminated due to the depth of the aquifer. Hydraulic control is eliminated as } \\
\text { not applicable for large plumes in transmissive aquifers. Containment by } \\
\text { injectable materials is retained. }\end{array}$ \\
\hline Removal, treatment, and disposal & $\begin{array}{l}\text { Removal, treatment, and disposal technologies are targeted at shallow } \\
\text { contamination only }\end{array}$ \\
\hline
\end{tabular}

\subsection{Screening Based on Scoping Calculations}

Based on the initial screening results, the potential remediation methods retained for further screening evaluation were compiled (Table 7.4). Scoping-level calculations to define the general scale of infrastructure and equipment, amendments needs, and other method-specific parameters were conducted to support assessment of each method remaining after the initial screening in terms of the effectiveness, implementability, and relative cost categories of the evaluation criteria.

Table 7.4. Remediation Methods Considered in Second Stage of Screening

\begin{tabular}{|c|c|}
\hline General Category & Remediation Method Category (applicable COC shown in parentheses) \\
\hline No Action & No Action (all) \\
\hline Institutional Controls & Institutional Controls (all) \\
\hline Containment & Injectable materials for stabilizing source areas (all) \\
\hline Monitored Natural Attenuation & Monitored Natural Attenuation (MNA) (all) \\
\hline Ex Situ Treatment & Pump-and-Treat \\
\hline \multirow[t]{7}{*}{ In-situ Treatment } & Chemical Stabilization by Injectable Apatite (uranium and plutonium) \\
\hline & Chemical Stabilization by Polyphosphate (uranium isotopes) \\
\hline & Injectable Zero-Valent Iron (chromate, Tc-99, and uranium isotopes) \\
\hline & Surfactant Flushing (all except tritium) \\
\hline & Down-well bioreactor/adsorption system (all except cyanide and tritium) \\
\hline & $\begin{array}{l}\text { Anaerobic Bioremediation } \\
\qquad \quad \text { Soluble substrate (all except cyanide and tritium) } \\
\quad-\quad \text { Direct reduction (chromate, uranium isotopes and Tc-99) } \\
\quad-\quad \text { Sulfate Reducing Bacteria } \\
\text { - } \quad \text { Injection of long-duration substrate (e.g., a non-aqueous substrate } \\
\text { such as vegetable oil) (all except cyanide and tritium) }\end{array}$ \\
\hline & $\begin{array}{l}\text { Permeable Reactive Barriers } \\
\text { - Injectable Zero-Valent Iron (chromate, Tc-99, and uranium } \\
\text { isotopes) } \\
\text { - Anaerobic Biobarrier (e.g., injection of long-duration substrate as } \\
\text { - } \quad \text { In barrier) (all except cyanide and tritium) } \\
\quad \text { isotopes) } \\
\text { - Injectable Apatite Barriers (uranium isotopes) } \\
\text { - Polyphosphate Barrier (uranium isotopes) }\end{array}$ \\
\hline
\end{tabular}


The following sections describe each potential remediation method and present scoping calculations to estimate the scale of infrastructure and equipment, amendments needs, and other method-specific parameters needed for evaluating the method against the criteria listed in Table 5.1 and for each COC group.

\subsubsection{Physical Containment}

Injection-based technologies for physical containment were examined. Injectable grout walls and freeze walls were identified as the two categories of injection technology potentially applicable to the 200-BP-5 Operable Unit. Injectable grout barriers are installed by jet-grouting from an injection well. Grout walls or "curtains” have been used extensively in the past for civil engineering projects, but less frequently to contain hazardous waste. Jet-grouted walls are constructed by injecting grout at very high pressure (up to 6,000 psi) into the subsurface. In general, a small-diameter pilot hole is drilled to the total depth of the barrier. The hole is jet-grouted from the bottom up. Multiple, closely spaced holes are grouted to form a horizontally continuous barrier. Jet-grout barriers have been built to depths greater than $61 \mathrm{~m}$, although below $30 \mathrm{~m}$ the vertical consistency, and thus continuity of jet-grouted barriers, are difficult to control or confirm. Typically, a Portland cement is used, although a variety of grout formulations may be used. Supersaturated solutions forming grouts in situ have been tested and applied for hydraulic control. However, this technique would have similar technical issues as for injection grouting and additional uncertainties related to its effectiveness. Thus, supersaturated grouts were not considered separately for the screening evaluation.

Frozen soil barrier technology (DOE 1999) consists of a series of subsurface heat transfer devices, known as thermoprobes, which are installed around a contaminant source and function to freeze the soil pore water. The barrier is maintained for a finite period of time until remediation or removal of the contaminants is complete. The thermoprobes are installed with drilling techniques. The subsurface thermoprobes utilize liquid-to-gas phase change of a passive refrigerant (carbon dioxide) to remove heat from the surrounding sediment. Above-ground refrigeration units and interconnecting piping are installed and operated. Insulation and a waterproof membrane are installed at grade to prevent heat gain from the surface and minimize infiltration. Frozen soil barriers offer advantages by being "self-healing” and allowing immobilization within the frozen matrix or containment. However, unlike the grout or cement barriers, frozen barriers do require electric power for the life of the barrier. Therefore, use of these barriers is best restricted to short or medium durations of 20 years or less. Demonstration projects have been limited to shallow depths (10 $\mathrm{m}$ ) and small areas (less than 0.15 acre).

Potentially, physical containment could be applied to all COC groups. However, the characteristics of physical containment are best suited to containing relatively small zones of contamination. For the screening evaluation, physical containment was only considered for application to small continuing source areas; in particular, application to containment of contaminants with a relatively short half life strontium 90 or tritium - in a continuing source of less than 1 acre.

Based on the technical uncertainty and high costs, physical containment is rejected as a potential remediation technology (see Sections 7.2.1.1 through 7.2.1.3). 


\subsubsection{Effectiveness}

\begin{tabular}{||l|l||}
\hline $\begin{array}{c}\text { Effectiveness } \\
\text { Screening Criteria } \\
\text { (see Table 5.1) }\end{array}$ & \multicolumn{1}{|c||}{ COC Group 2 (short-lived radionuclide continuing source) } \\
\hline \hline Reliably meet goal? & $\begin{array}{l}\text { Significant uncertainty is associated with the ability to physically contain the relatively } \\
\text { large contaminated volume of a continuing source area at the depths of the 200-BP-5 } \\
\text { Operable Unit. Grout walls may be less effective for containing solvent over the long } \\
\text { term due to diffusion of contaminant through the grout wall. Freeze walls would require } \\
\text { active operation over a very long time period. }\end{array}$ \\
\hline $\begin{array}{l}\text { Produce hazardous } \\
\text { products? }\end{array}$ & No hazardous byproducts would be produced. \\
\hline $\begin{array}{l}\text { Negatively impact to } \\
\text { other COC? }\end{array}$ & No negative impacts on other COC are expected. \\
\hline $\begin{array}{l}\text { Treat target volume? } \\
\text { Efficacy of physical containment placement depends on target volume depth. There is } \\
\text { some uncertainty with placement of effective containment at the depth to groundwater. }\end{array}$ \\
\hline $\begin{array}{l}\text { Cause risk during } \\
\text { construction or } \\
\text { operation? }\end{array}$ & Construction risk would be from necessary drilling. \\
\hline \hline
\end{tabular}

\subsubsection{Implementability}

\begin{tabular}{||l|l||}
\hline $\begin{array}{c}\text { Implementability } \\
\text { Screening Criteria } \\
\text { (see Table 5.1) }\end{array}$ & \multicolumn{1}{|c||}{ COC Group 1 (short-lived radionuclide continuing source) } \\
\hline \hline $\begin{array}{l}\text { Reliably constructed } \\
\text { and operated? }\end{array}$ & $\begin{array}{l}\text { Grout walls effectiveness is impacted by stratigraphy and depth. Freeze walls are less } \\
\text { sensitive to stratigraphy. }\end{array}$ \\
\hline $\begin{array}{l}\text { Reasonable } \\
\text { consumable usage? }\end{array}$ & $\begin{array}{l}\text { While a significant amount of grout would be needed for a 1 acre containment, } \\
\text { consumables are not significant issue for physical containment technologies. }\end{array}$ \\
\hline
\end{tabular}

\subsubsection{Relative Cost}

Cost factors for physical containment are primarily associated with the large number of boreholes necessary due to the limited radius of injection for grout or for effective freezing for freeze walls. Even with an optimistic radius of influence of 3-5 m, a large number of boreholes is needed to contain a 1 acre volume. Using costs at the high end of the range for injection grouting technology (\$20 per square foot of panel area), a barrier $3 \mathrm{~m}$ thick by $250 \mathrm{~m}$ long by $20 \mathrm{~m}$ deep would cost in the range of $\$ 1 \mathrm{M}$. Costs for an application to the 200-BP-5 Operable Unit are expected to be higher than this estimate due to higher Hanford drilling costs (due to the presence of radioactive contamination and geologic difficulties) and an overall depth of application that is deeper than existing applications. Freeze walls are expected to have a similar capital cost as for injected grout walls, but active operation to maintain cooling would be required over a very long time period.

\subsubsection{Monitored Natural Attenuation}

The EPA Office of Solid Waste and Emergency Response (OSWER) identifies the requirements for MNA in "Use of Monitored Natural Attenuation at Superfund, RCRA Corrective Action, and 
Underground Storage Tank Sites” (OSWER Directive 9200.4-17P, EPA 1999), hereafter referred to as the "OSWER MNA Directive.” Quotations from this directive are shown in italics font. The OSWER MNA Directive defines natural attenuation processes as follows. The "natural attenuation processes" that are at work in such a remediation approach [MNA] include a variety of physical, chemical, or biological processes that, under favorable conditions, act without human intervention to reduce the mass, toxicity, mobility, volume, or concentration of contaminants in soil or groundwater. These in-situ processes include biodegradation; dispersion; dilution; sorption; volatilization; radioactive decay; and chemical or biological stabilization, transformation, or destruction of contaminants.

The OSWER MNA Directive provides some key considerations for determining whether MNA is an appropriate remedy for a site. These considerations and a discussion relative to each COC group are listed below.

1. Whether the contaminants present in soil or groundwater can be effectively remediated by natural attenuation processes.

- COC Group 1 - Natural attenuation processes acting on COC Group 1 include sorption, dispersion, and dilution. These mechanisms have the potential to reduce COC concentration and limit plume migration, but quantitative studies to define the extent of attenuation have not been conducted.

- COC Group 2 - Natural attenuation processes acting on nitrate and cyanide include dispersion and dilution. These mechanisms have the potential to reduce nitrate or cyanide concentrations and limit plume migration, but quantitative studies to define the extent of attenuation have not been conducted.

- COC Group 3 - Natural attenuation processes acting on tritium include radioactive decay, dispersion, and dilution. These mechanisms have the potential to significantly reduce tritium concentrations and limit plume migration.

2. Whether or not the contaminant plume is stable and the potential for the environmental conditions that influence plume stability to change over time.

- COC Group 1 - Plume stability was not evaluated as part of the screening evaluation. Conditions over time will act to reduce the groundwater flow rate because surface water discharges have been significantly decreased. Sorption, dispersion, and dilution are not expected to change over time.

- $\quad$ COC Group 2 - Plume stability was not evaluated as part of the screening evaluation. Conditions over time will act to reduce the groundwater flow rate because surface water discharges have been significantly decreased. Dispersion and dilution are not expected to change over time.

- $\quad$ COC Group 3 - Plume stability was not evaluated as part of the screening evaluation. Conditions over time will act to reduce the groundwater flow rate because surface water discharges have been significantly decreased. The decay rate, dispersion, and dilution are not expected to change over time. 
3. Whether human health, drinking water supplies, other groundwaters, surface waters, ecosystems, sediments, air, or other environmental resources could be adversely impacted as a consequence of selecting MNA as the remediation options.

For all COC, direct use of groundwater is the only likely exposure pathway. Thus, adverse impacts depend on the controls on groundwater usage, the volume of aquifer impacted by the contaminant, and the timeframe over which the groundwater remains contaminated above action levels. As such, this aspect of MNA is not directly considered in the screening evaluation.

4. Current and projected demand for the affected resource over the time period that the remedy will remain in effect.

The groundwater demand is a function of administrative decisions, the volume of aquifer impacted by the contaminant, and the timeframe over which the groundwater remains contaminated above action levels. As such, this aspect of MNA is not directly considered in the screening evaluation.

5. Whether the contamination, either by itself or as an accumulation with other nearby sources (onsite or offsite), will exert a long-term detrimental impact on available water supplies or other environmental resources.

The groundwater availability is a function of administrative decisions, the volume of aquifer impacted by the contaminant, and the timeframe over which the groundwater remains contaminated above action levels. As such, this aspect of MNA is not directly considered in the screening evaluation.

6. Whether the estimated timeframe of remediation is reasonable compared to timeframes required for other more active methods (including anticipated effectiveness of various remedial approaches on different portions of the contaminated soil and/or groundwater).

The timeframe for MNA is likely longer than the timeframe for active remedies. The reasonableness of the timeframe will be considered in the detailed analysis of the full feasibility study. As such, this aspect of MNA is not directly considered in the screening evaluation.

7. The nature and distribution of sources of contamination and whether these sources have been, or can be, adequately controlled.

Due to the large vadose zone with uncertain contaminant distribution, there is some uncertainty in the long-term nature of the sources. However, efforts are underway to examine potential source control methods.

8. Whether the resulting transformation products present a greater risk, due to increased toxicity and/or mobility, than do the parent contaminants.

None of the degradation or decay products for those COC that degrade or decay by natural processes under the Hanford aquifer conditions are hazardous. 
9. The impact of existing and proposed active remediation measures upon the MNA component of the remedy, or the impact of remediation measures or other operations/activities (e.g., pumping wells) in close proximity to the site.

There are no existing interim remedial actions (e.g., pump-and-treat) and most active remedies under consideration have a positive impact on natural attenuation by reducing contaminant mass/concentration and addressing source areas. Consideration of any negative impacts on MNA will be included in the assessment of potential future active remedies.

10. Whether reliable site-specific mechanisms for implementing institutional controls (e.g., zoning ordinances) are available, and if an institution responsible for their monitoring and enforcement can be identified.

The Hanford Site has existing mechanisms for implementing institutional controls that are expected to remain viable for the foreseeable future.

Based on the evaluation of effectiveness, implementability, and relative cost presented below, MNA is retained as a potential remediation method for all COC groups (see Sections 7.2.2.1 through 7.2.2.3).

\subsubsection{Effectiveness}

\begin{tabular}{||l|l|l|l||}
\hline $\begin{array}{c}\text { Effectiveness } \\
\text { Screening Criteria } \\
\text { (see Table 5.1) }\end{array}$ & \multicolumn{1}{|c|}{ COC Group 1 } & \multicolumn{1}{c||}{ COC Group 2 } & \multicolumn{1}{c||}{ COC Group 3 } \\
\hline \hline Reliably meet goal? & $\begin{array}{l}\text { MNA will } \\
\text { moderately decrease } \\
\text { concentrations over } \\
\text { time due to sorption, } \\
\text { dispersion and } \\
\text { dilution. }\end{array}$ & $\begin{array}{l}\text { MNA will } \\
\text { moderately decrease } \\
\text { concentrations over } \\
\text { time due to } \\
\text { dispersion and } \\
\text { dilution. }\end{array}$ & $\begin{array}{l}\text { MNA has the } \\
\text { potential to } \\
\text { significantly } \\
\text { decrease } \\
\text { contaminant } \\
\text { concentration. }\end{array}$ \\
\hline $\begin{array}{l}\text { Produce hazardous } \\
\text { products? }\end{array}$ & $\begin{array}{l}\text { MNA does not } \\
\text { produce hazardous } \\
\text { byproducts. }\end{array}$ & $\begin{array}{l}\text { MNA does not } \\
\text { produce hazardous } \\
\text { byproducts. }\end{array}$ & $\begin{array}{l}\text { MNA does not } \\
\text { produce hazardous } \\
\text { byproducts. }\end{array}$ \\
\hline $\begin{array}{l}\text { Negatively impact } \\
\text { to other COC? }\end{array}$ & $\begin{array}{l}\text { MNA of one COC } \\
\text { does not negatively } \\
\text { impact another. }\end{array}$ & $\begin{array}{l}\text { MNA of one COC } \\
\text { does not negatively } \\
\text { impact another. }\end{array}$ & $\begin{array}{l}\text { MNA of one COC } \\
\text { does not negatively } \\
\text { impact another. }\end{array}$ \\
\hline $\begin{array}{l}\text { Treat target } \\
\text { volume? }\end{array}$ & $\begin{array}{l}\text { MNA is } \\
\text { independent of } \\
\text { volume. }\end{array}$ & $\begin{array}{l}\text { MNA is } \\
\text { independent of } \\
\text { volume. }\end{array}$ & $\begin{array}{l}\text { MNA is } \\
\text { independent of } \\
\text { volume. }\end{array}$ \\
\hline $\begin{array}{l}\text { Cause risk during } \\
\text { construction or } \\
\text { operation? }\end{array}$ & $\begin{array}{l}\text { MNA has no } \\
\text { construction or } \\
\text { operational risk. }\end{array}$ & $\begin{array}{l}\text { MNA has no } \\
\text { construction or } \\
\text { operational risk. }\end{array}$ & $\begin{array}{l}\text { MNA has no } \\
\text { construction or } \\
\text { operational risk. }\end{array}$ \\
\hline \hline
\end{tabular}




\subsubsection{Implementability}

\begin{tabular}{||l|l|l|l||}
\hline $\begin{array}{c}\text { Implementability } \\
\text { Screening Criteria } \\
\text { (see Table 5.1) }\end{array}$ & \multicolumn{1}{|c|}{ COC Group 1 } & \multicolumn{1}{|c||}{ COC Group 2 } & \multicolumn{1}{c||}{ COC Group 3 } \\
\hline \hline $\begin{array}{l}\text { Reliably constructed } \\
\text { and operated? }\end{array}$ & $\begin{array}{l}\text { MNA has no } \\
\text { construction or } \\
\text { operational } \\
\text { problems, but the } \\
\text { need for long-term } \\
\text { monitoring and the } \\
\text { potential need for a } \\
\text { contingency remedy } \\
\text { if natural } \\
\text { attenuation does not } \\
\text { limit plume } \\
\text { migration are } \\
\text { operational risks. }\end{array}$ & $\begin{array}{l}\text { MNA has no } \\
\text { construction or } \\
\text { operational } \\
\text { problems, but the } \\
\text { need for long-term } \\
\text { monitoring and the } \\
\text { potential need for a } \\
\text { contingency remedy } \\
\text { if natural } \\
\text { attenuation does not } \\
\text { limit plume } \\
\text { migration are } \\
\text { operational risks. }\end{array}$ & $\begin{array}{l}\text { MNA has no } \\
\text { construction or } \\
\text { operational } \\
\text { problems, but the } \\
\text { need for long-term } \\
\text { potential need for a } \\
\text { contingency remedy } \\
\text { if natural } \\
\text { attenuation does not } \\
\text { limit plume } \\
\text { migration are } \\
\text { operational risks. }\end{array}$ \\
\hline $\begin{array}{l}\text { Reasonable } \\
\text { consumable usage? }\end{array}$ & $\begin{array}{l}\text { MNA has no } \\
\text { significant } \\
\text { consumable usage. }\end{array}$ & $\begin{array}{l}\text { MNA has no } \\
\text { significant } \\
\text { consumable usage. }\end{array}$ & $\begin{array}{l}\text { MNA has no } \\
\text { significant } \\
\text { consumable usage. }\end{array}$ \\
\hline \hline
\end{tabular}

\subsubsection{Relative Cost}

MNA is expected to have a cost comparable to other options. The primary cost factors are costs for the initial MNA evaluation, monitoring wells, and long-term monitoring.

\subsubsection{Pump-and-Treat}

Pump-and-treat is a baseline remedy for all COC groups and, as such, will be carried forward for the more detailed analysis in the feasibility study.

\subsubsection{Injectable Apatite Solution}

Hydroxyapatite $\left[\mathrm{Ca}_{5}\left(\mathrm{PO}_{4}\right)_{3} \mathrm{OH}\right]$ has been found to be very effective in sequestration of many dissolved metals including strontium, plutonium, and uranium. Such divalent metal oxyanions do react with dissolved phosphate to precipitate and immobilize the heavy metal. Apatite sequestration is expected to be minimally effective with chromium, technetium, and iodine groundwater contamination. Thus, for the screening evaluation, apatite was only considered for applicable to uranium, strontium and possibly plutonium as part of COC Group 1 (Fuller et al. 2002; Flury and Harsh 2000; Bostick et al.

2003). Because of the depth to groundwater, application of solid phase apatite is not feasible and will not be considered as a viable technology for the site. However, apatite minerals can be formed in situ from injection of soluble reagents (Moore et al. 2004). This method relies on injection of calcium citrate and phosphate solutions. The calcium is complexed with citrate during the injection and does not react with the phosphate until the citrate is degraded by microorganisms in the subsurface. Thus, the apatite formation can be distributed over a radial distance of meters to $\sim 10 \mathrm{~m}$ away from the injection well depending on the subsurface hydrology and the microbial citrate degradation rate. This technique is currently being tested for application to strontium contamination at the Hanford 100-N Area. Injectable apatite would be considered an innovative treatment option. 
Based on the evaluation of effectiveness, implementability, and relative cost presented below, injectable apatite is retained as a potential remediation method for uranium and possibly plutonium (part of COC Group 1) over an areal extent of less than 5 acres. This is an innovative technology that would likely need treatability testing (see Sections 7.2.4.1 through 7.2.4.3).

\subsubsection{Effectiveness}

\begin{tabular}{||l|l||}
\hline $\begin{array}{c}\text { Effectiveness } \\
\text { Screening Criteria } \\
\text { (see Table 5.1) }\end{array}$ & \multicolumn{1}{c||}{ COC Group 1 (uranium and plutonium only) } \\
\hline \hline Reliably meet goal? & $\begin{array}{l}\text { Likely reliable to reduce concentrations in a small volume. } \\
\text { Laboratory-scale studies show promise. Field-scale testing yet to be } \\
\text { conducted. }\end{array}$ \\
\hline $\begin{array}{l}\text { Produce hazardous } \\
\text { products? }\end{array}$ & No hazardous byproducts are produced. \\
\hline $\begin{array}{l}\text { Negatively impact to } \\
\text { other COC? }\end{array}$ & $\begin{array}{l}\text { Likely no impact if applied in a small volume such as the uranium or } \\
\text { plutonium plume. Residual phosphate could stimulate } \\
\text { microbiological growth. }\end{array}$ \\
\hline Treat target volume? & $\begin{array}{l}\text { Distribution of the reagents meters to } ~ 10 \text { m from the injection point } \\
\text { is expected. As such, volumetric treatment of up to } 5 \text { acres could be } \\
\text { achieved with a reasonable number of access wells. }\end{array}$ \\
\hline $\begin{array}{l}\text { Cause risk during } \\
\text { construction or } \\
\text { operation? }\end{array}$ & Construction risk would be from necessary drilling. \\
\hline
\end{tabular}

\subsubsection{Implementability}

\begin{tabular}{||l|l||}
\hline $\begin{array}{c}\text { Implementability } \\
\text { Screening Criteria } \\
\text { (see Table 5.1) }\end{array}$ & \multicolumn{1}{|c||}{ COC Group 1 (uranium and plutonium only) } \\
\hline \hline $\begin{array}{l}\text { Reliably constructed } \\
\text { and operated? }\end{array}$ & $\begin{array}{l}\text { Uniform distribution of reagents possible with proper engineering } \\
\text { and hydraulic control. Treatability testing is needed. }\end{array}$ \\
\hline $\begin{array}{l}\text { Reasonable } \\
\text { consumable usage? }\end{array}$ & $\begin{array}{l}\text { Treatability testing is needed to assess design of the remediation } \\
\text { system. }\end{array}$ \\
\hline
\end{tabular}

\subsubsection{Relative Cost}

The injectable apatite remediation method is an innovative technology still under development. Cost factors are primarily related to the radius of influence that can be obtained. It is expected that a radius of influence similar to injection of a long-duration substrate for anaerobic bioremediation will be possible. As such, costs for injectable apatite could be comparable to other technologies at an areal extent of less than 5 acres, where well costs would be similar to an anaerobic bioremediation application.

\subsubsection{Stabilization by Polyphosphate}

Another phosphate-based technology for stabilization of uranium using phosphate is presently in development. This technology uses injection of liquid polyphosphate to stabilize uranium. It is not applicable to the other COC. This technology stabilizes uranium by a different mechanism than apatite stabilization. 
The process uses polymers of phosphate to release phosphate at a slow, controlled rate into groundwater downgradient of the application point. The presence of phosphate in groundwater, even in minor concentrations $\left(10^{-8} \mathrm{M}\right)$, promotes the formation of autunite-group minerals, $\mathrm{X}_{3-\mathrm{n}}{ }^{(\mathrm{n})^{*}}\left[\left(\mathrm{UO}_{2}\right)\left(\mathrm{PO}_{4}\right)\right]_{2} \cdot \mathrm{XH}_{2} \mathrm{O}$, thereby limiting the mobility of the uranyl cation $\left(\mathrm{UO}_{2}{ }^{2+}\right)$ in the subsurface environment. The use of soluble long-chain polyphosphate reagent delays precipitation of the autunite, thereby mitigating plugging of the formation near the application point. By tailoring the polyphosphate chain, the hydrolysis reaction that releases the phosphate into the water can be engineered and the uranium stabilization rate controlled. Because autunite sequesters uranium in the oxidized form, $\mathrm{U}^{6+}$, rather than forcing reduction to $\mathrm{U}^{4+}$, the possibility of re-oxidation and subsequent re-mobilization is negated. Extensive laboratory testing demonstrates the very low solubility of autunite. In addition to autunite, excess phosphorous may result in apatite mineral formation, providing a secondary, long-term source of treatment capacity.

Deployment polyphosphate may be designed to treat a horizontal extent as well as vertical zone of uranium in the groundwater and at the water-table interface. The liquid form of the reagent facilitates application to and transport within the contaminated groundwater plume. Uranium transport studies in columns packed with contaminated sediment from the Hanford 300 Area indicate that a polyphosphate solution reduces the concentration of uranium in water to near the drinking water standard $(30 \mu \mathrm{g} / \mathrm{L})$ (Wellman et al. 2006). Polyphosphate would be considered an innovative treatment option.

Based on the evaluation of effectiveness, implementability, and relative cost presented below, polyphosphate is retained as a potential remediation method for uranium (part of COC Group 1) over an areal extent of less than 5 acres. This is an innovative technology that would likely need treatability testing (see Sections 7.2.5.1 through 7.2.5.3).

\subsubsection{Effectiveness}

\begin{tabular}{||l|l||}
\hline $\begin{array}{c}\text { Effectiveness } \\
\text { Screening Criteria } \\
\text { (see Table 5.1) }\end{array}$ & \multicolumn{1}{c||}{ COC Group 1 (uranium only) } \\
\hline \hline Reliably meet goal? & $\begin{array}{l}\text { Likely reliable to reduce concentrations in a small volume. } \\
\text { Laboratory-scale studies show promise. Field-scale testing yet to be } \\
\text { conducted. }\end{array}$ \\
\hline $\begin{array}{l}\text { Produce hazardous } \\
\text { products? }\end{array}$ & No hazardous byproducts are produced. \\
\hline $\begin{array}{l}\text { Negatively impact to } \\
\text { other COC? }\end{array}$ & $\begin{array}{l}\text { Likely no impact if applied in a small volume such as the uranium } \\
\text { plume. Residual phosphate could stimulate microbiological growth. }\end{array}$ \\
\hline $\begin{array}{l}\text { Treat target volume? } \\
\text { Distribution of the polyphosphate meters to } 10 \text { m from the injection } \\
\text { point is expected. As such, volumetric treatment of up to } 5 \text { acres } \\
\text { could be achieved with a reasonable number of access wells. }\end{array}$ \\
\hline $\begin{array}{l}\text { Cause risk during } \\
\text { construction or } \\
\text { operation? }\end{array}$ & Construction risk would be from necessary drilling. \\
\hline
\end{tabular}




\subsubsection{Implementability}

\begin{tabular}{||l|l||}
\hline $\begin{array}{l}\text { Implementability Screening } \\
\text { Criteria (see Table 5.1) }\end{array}$ & \multicolumn{1}{c||}{ COC Group 1 (uranium only) } \\
\hline \hline $\begin{array}{l}\text { Reliably constructed and } \\
\text { operated? }\end{array}$ & $\begin{array}{l}\text { Uniform distribution of polyphosphate possible with proper engineering and } \\
\text { hydraulic control. Treatability testing is needed. }\end{array}$ \\
\hline $\begin{array}{l}\text { Reasonable consumable } \\
\text { usage? }\end{array}$ & Treatability testing is needed to assess design of the remediation system. \\
\hline
\end{tabular}

\subsubsection{Relative Cost}

The polyphosphate remediation method is an innovative technology still under development. Cost factors are primarily related to the radius of influence that can be obtained. It is expected that a radius of influence similar to injection of a long-duration substrate for anaerobic bioremediation will be possible. As such, costs for polyphosphate could be comparable to other technologies at an areal extent of less than 5 acres, where well costs would be similar to an anaerobic bioremediation application.

\subsubsection{Injectable Zero-Valent Iron}

Emplacement of zero-valent iron particles in the subsurface provides an electron source for reduction of chromium, technetium-99, uranium, and nitrate (parts of COC Groups 1 and 2). Typically, zero-valent iron is applied as a permeable reactive barrier. Potentially, it could be deployed in a manner more suitable for volumetric treatment (e.g., Quinn et al. 2005). However, for volumetric treatment, the extent to which the particles can be distributed is a key issue for consideration. Present technology permits placement of small-scale iron particles from wells to radial distances of about 3-7 m (GeoSierra 2005). Similarly, low radial influences are observed with current applications of emulsified zero-valent iron (Quinn et al. 2005 and personal communication J. Quinn). Because large quantities of zero-valent iron are needed for large-volume treatment (see Table 7.6) and the radius of influence is small, zero-valent iron is typically limited to small-volume applications or for permeable reactive barrier applications (see Section 7.2.10).

Based on the evaluation of effectiveness, implementability, and relative cost presented below, zerovalent iron for volumetric treatment is eliminated as a potential remediation method for all COC groups (see Sections 7.2.6.1 through 7.2.6.3).

Table 7.5. Zero-Valent Iron Required as a Function of Aquifer Volume

\begin{tabular}{||l|c|c||}
\hline \multicolumn{1}{|c|}{ Radius or Areal Extent } & $\begin{array}{c}\text { Volume of Aquifer } \\
\left(\mathrm{m}^{3}\right)\end{array}$ & $\begin{array}{c}\text { Mass of Zero-Valent Iron } \\
(\mathrm{kg})\end{array}$ \\
\hline \hline Radius of $3 \mathrm{~m}$ at $20 \mathrm{~m}$ depth & 565 & 54,000 \\
\hline Radius of $7 \mathrm{~m}$ at $20 \mathrm{~m}$ depth & 3,079 & 295,000 \\
\hline $\begin{array}{l}\text { Radius of } 20 \text { (multiple wells } \\
\text { needed) }\end{array}$ & 25,133 & $7,300,000$ \\
\hline $\begin{array}{l}4,000 \mathrm{~m}^{2} \text { ( } 1 \text { acre) at } 20 \mathrm{~m} \text { depth } \\
\text { (multiple wells needed) }\end{array}$ & 80,000 & \\
\hline $\begin{array}{l}\text { (a) Calculated using a porosity of } 0.3 \text { and for a 10\% zero-valent iron emulsion filling } \\
\text { 20\% of the pore space. }\end{array}$ \\
\hline
\end{tabular}




\subsubsection{Effectiveness}

\begin{tabular}{||l|l|l||}
\hline $\begin{array}{l}\text { Effectiveness Screening } \\
\text { Criteria (see Table 5.1) }\end{array}$ & \multicolumn{1}{|c|}{ COC Group 1 } & \multicolumn{1}{|c||}{ COC Group 2 } \\
\hline \hline Reliably meet goal? & $\begin{array}{l}\text { Likely reliable for } \\
\text { chromium. Tc-99 and } \\
\text { uranium likely reduced } \\
\text { to meet goal, but can re- } \\
\text { oxidize over time. }\end{array}$ & $\begin{array}{l}\text { Likely reliable for } \\
\text { nitrate. }\end{array}$ \\
\hline $\begin{array}{l}\text { Produce hazardous } \\
\text { products? }\end{array}$ & $\begin{array}{l}\text { No hazardous } \\
\text { byproducts. }\end{array}$ & $\begin{array}{l}\text { No hazardous } \\
\text { byproducts. }\end{array}$ \\
\hline $\begin{array}{l}\text { Negatively impact to } \\
\text { other COC? }\end{array}$ & $\begin{array}{l}\text { No negative impacts } \\
\text { expected. }\end{array}$ & $\begin{array}{l}\text { No negative impacts } \\
\text { expected. }\end{array}$ \\
\hline Treat target volume? & $\begin{array}{l}\text { Only applicable for } \\
\text { small volume not likely } \\
\text { relevant to overall COC } \\
\text { Group 1 plume } \\
\text { treatment. }\end{array}$ & $\begin{array}{l}\text { Only applicable for } \\
\text { small volume; not } \\
\text { likely relevant to } \\
\text { overall nitrate plume } \\
\text { treatment. }\end{array}$ \\
\hline $\begin{array}{l}\text { Cause risk during } \\
\text { construction or } \\
\text { operation? }\end{array}$ & $\begin{array}{l}\text { Primary risk would be } \\
\text { from significant amount } \\
\text { of necessary drilling. }\end{array}$ & $\begin{array}{l}\text { Primary risk would be } \\
\text { from significant amount } \\
\text { of necessary drilling. }\end{array}$ \\
\hline \hline
\end{tabular}

\subsubsection{Implementability}

\begin{tabular}{||l|l|l||}
\hline $\begin{array}{c}\text { Implementability } \\
\text { Screening Criteria } \\
\text { (see Table 5.1) }\end{array}$ & \multicolumn{1}{|c||}{ COC Group 1 } & \multicolumn{1}{|c||}{ COC Group 2 } \\
\hline \hline $\begin{array}{l}\text { Reliably constructed } \\
\text { and operated? }\end{array}$ & $\begin{array}{l}\text { Uniform distribution } \\
\text { of iron with a long } \\
\text { well screen may be } \\
\text { problematic. Very } \\
\text { large number of } \\
\text { wells necessary. }\end{array}$ & $\begin{array}{l}\text { Uniform distribution } \\
\text { of iron with a long } \\
\text { well screen may be } \\
\text { problematic. Very } \\
\text { large number of } \\
\text { wells necessary. }\end{array}$ \\
\hline Reasonable \\
consumable usage? & $\begin{array}{l}\text { Very large amounts } \\
\text { of iron necessary for } \\
\text { volumetric } \\
\text { treatment. }\end{array}$ & $\begin{array}{l}\text { Very large amounts } \\
\text { of iron necessary for } \\
\text { volumetric } \\
\text { treatment. }\end{array}$ \\
\hline \hline
\end{tabular}

\subsubsection{Relative Cost}

Cost factors for zero-valent iron are associated with the relatively high reagent usage and large number of wells needed due to the limited radius of injection. Nano-zero-valent iron in powder form costs over \$16 per pound, and emulsified zero-valent iron costs more than \$20 per gallon for a 10\% iron solution (personal communication, J. Greg Booth, Applied Science \& Advanced Technologies, Inc.). The cost of the emulsified zero-valent iron, even for a treatment cylinder volume represented by a $20-\mathrm{m}$ radius and a depth interval of $20 \mathrm{~m}$, would be on the order of $\$ 80 \mathrm{M}$. Costs for zero-valent iron as a volumetric treatment are expected to be higher than other potential remedies due to the high reagent usage and large number of wells for the relatively large treatment volumes associated with 200-BP-5 COC. 


\subsubsection{Surfactant Flushing}

This technology employs surfactant mixtures (i.e., non-ionic and anionic) in injection wells at levels generally around $1 \%$ to $3 \%$ with or without additional chemicals (co-solvents, alcohols, inorganic salts, etc.) to promote the mobilization and/or solubilization of nonaqueous phase liquid (NAPL). Solubilization of sorbed contaminants may also occur. The surfactants function by lowering the NAPL-water interfacial tension and decreasing capillary forces within the porous media, which creates a microemulsion system and solubilizes the contaminant. In most demonstrations, surfactants or co-solvents are pumped through the aquifer displacing at least one or more pore volumes of groundwater, followed by several pore volumes of water to remove the residual surfactant. Various well configurations are used including single vertical circulation wells and injection/extraction well networks. Recovered contaminant with recovered surfactant is processed ex-situ using a variety of treatment processes.

Surfactant flushing is not likely to be appropriate for treating COC in the 200-BP-5 because of the difficulty in selecting and applying an effective yet selective surfactant to inorganic contaminants that would not also mobilize large quantities of non-target minerals in the formation. Thus, for the screening evaluation, surfactant flushing was not considered further.

\subsubsection{Down-Well System}

Down-well treatment systems place a bioreactor or adsorption media within the well bore. Such technology is presently developmental and has not been deployed at a large scale. The technology requires treating groundwater within the relatively limited volume of the well bore. Biological treatment systems require a definite control volume to contain the biological process for a specific detention or reaction time. Down-well sorption systems are limited by the media-holding capacity of the well bore. Consequently, frequent media replacement may be needed. For the screening evaluation, down-well systems were considered as potentially applicable to COC Group 1.

Based on the evaluation of effectiveness, implementability, and relative cost presented below, downwell treatment is eliminated as a potential remediation method (see Sections 7.2.8.1 through 7.2.8.3).

\subsubsection{Effectiveness}

\begin{tabular}{||l|l||}
\hline $\begin{array}{c}\text { Effectiveness Screening } \\
\text { Criteria (see Table 5.1) }\end{array}$ & \multicolumn{1}{c|}{ COC Group 1 } \\
\hline \hline Reliably meet goal? & $\begin{array}{l}\text { Significant uncertainty in the ability to reduce } \\
\text { contaminant concentration. }\end{array}$ \\
\hline $\begin{array}{l}\text { Produce hazardous } \\
\text { products? }\end{array}$ & No hazardous by products. \\
\hline $\begin{array}{l}\text { Negatively impact to } \\
\text { other COC? }\end{array}$ & No negative impacts expected. \\
\hline Treat target volume? & $\begin{array}{l}\text { Potentially applicable to the same aquifer volume as for } \\
\text { in-well air stripping based on expected recirculation } \\
\text { patterns. }\end{array}$ \\
\hline $\begin{array}{l}\text { Cause risk during } \\
\text { construction or operation? }\end{array}$ & $\begin{array}{l}\text { Primary risk would be from significant amount of drilling } \\
\text { necessary. }\end{array}$ \\
\hline \hline
\end{tabular}




\subsubsection{Implementability}

\begin{tabular}{||l|l||}
\hline $\begin{array}{c}\text { Implementability } \\
\text { Screening Criteria (see } \\
\text { Table 5.1) }\end{array}$ & \multicolumn{1}{c|}{ COC Group 1 } \\
\hline \hline $\begin{array}{l}\text { Reliably constructed and } \\
\text { operated? }\end{array}$ & $\begin{array}{l}\text { Complex construction and maintenance concerns due to } \\
\text { small volume available for the treatment system within } \\
\text { the well. }\end{array}$ \\
\hline $\begin{array}{l}\text { Reasonable consumable } \\
\text { usage? }\end{array}$ & $\begin{array}{l}\text { Reagent or consumable costs could be uneconomic } \\
\text { based upon limited operating efficiencies. }\end{array}$ \\
\hline
\end{tabular}

\subsubsection{Relative Cost}

Cost factors for down-well treatment include well drilling and maintenance of the treatment process. The number of wells is highly dependent on the effective radius of influence for contaminant extraction that is obtained. A site-specific treatability test would likely be needed to determine the radius of influence. Based on the estimated radii of influence and associated treatment volumes listed in Table 7.7, the number of wells per treatment volume can be estimated. For an areal treatment extent above about 25 acres, the number of wells required for application of down-well treatment will likely increase cost significantly compared to the cost for other viable options.

Applied as a treatment barrier, well spacing can be determined from information in Table 7.7. Costs are directly related to the radius of influence by determining the number of wells needed for a barrier application.

\subsubsection{Anaerobic Bioremediation}

Anaerobic dechlorination reactions require that an appropriate substrate is present, and the dechlorinating bacteria can effectively compete for the substrate against other microorganisms that can also use the substrate with other electron acceptors. Nitrate, chromium, technetium-99, and uranium can also be reduced under anaerobic conditions and converted to non-hazardous products (for nitrate) or to insoluble chemical forms (for chromium, technetium-99, and uranium). The biomass that grows during anaerobic bioremediation may also increase the adsorption of other contaminants such as iodine-129, potentially enhanced through reduction of the iodine (Muramatsu et al. 2004). Thus, anaerobic bioremediation is potentially applicable to part of COC Groups 1 and 2.

In situ anaerobic bioremediation relies on effective distribution of substrate and activity of appropriate bacteria. A groundwater recirculation system could be used to distribute a soluble substrate (e.g., molasses) over large distances to attempt reduction of nitrate, chromium, technetium-99, and uranium. The ability to stimulate appropriate microbial activity would need to be evaluated to confirm whether remediation goals will likely be met.

In situ anaerobic bioremediation could also be implemented by distributing a long-duration substrate such as vegetable oil into the aquifer. Because the substrate is less accessible to the bacteria, it is not consumed as it is distributed and can provide a long-term food supply once in place. The key property with this technology is the hydraulic conductivity of the aquifer. The radius of the treatment zone depends on how well the substrate can be injected into and distributed through the aquifer formation. A 
secondary property of interest is the length of time that the substrate lasts, which impacts the frequency of "regenerating" the treatment zone. The radius of influence for long-duration substrate injection will be less than that for a soluble substrate. Functionally, a radius of about $7 \mathrm{~m}$ for oil distribution is similar to what has been achieved for other applications of this technology.

Based on the evaluation of effectiveness, implementability, and relative cost (presented below), in situ anaerobic bioremediation is retained as a potential remediation method for COC Groups 1 and 2 for application to treat an areal extent of up to 5 acres (see Sections 7.2.9.1 through 7.2.9.3). For thick contaminated intervals, multiple injection well intervals would likely be needed.

\subsubsection{Effectiveness}

\begin{tabular}{|c|c|c|}
\hline $\begin{array}{l}\text { Effectiveness } \\
\text { Screening Criteria } \\
\text { (see Table 5.1) }\end{array}$ & COC Group 1 & $\begin{array}{l}\text { COC Group } 2 \text { (nitrate } \\
\text { only) }\end{array}$ \\
\hline Reliably meet goal? & $\begin{array}{l}\text { There is moderate uncertainty in meeting the goals for Tc- } \\
99 \text { and uranium because these compounds can reoxidize } \\
\text { readily and become mobile again after being microbially } \\
\text { reduced and temporarily immobilized. It is likely that } \\
\text { goals for chromium could be met because it remains stable } \\
\text { and immobile after microbial reduction. Increased } \\
\text { adsoption of I-129 and reduction may also occur. }\end{array}$ & $\begin{array}{l}\text { It is likely that goals for } \\
\text { nitrate could be met } \\
\text { because it will likely be } \\
\text { reduced to nitrogen gas. }\end{array}$ \\
\hline $\begin{array}{l}\text { Produce hazardous } \\
\text { products? }\end{array}$ & No hazardous byproducts. & $\begin{array}{l}\text { Likely no hazardous } \\
\text { byproducts. }\end{array}$ \\
\hline $\begin{array}{l}\text { Negatively impact to } \\
\text { other COC? }\end{array}$ & No negative impacts expected. & $\begin{array}{l}\text { No negative impacts } \\
\text { expected. }\end{array}$ \\
\hline Treat target volume? & $\begin{array}{l}\text { Bioremediation can treat large or small volumes, but will } \\
\text { require numerous wells for larger volumes due to a limited } \\
\text { radius of influence for substrate distribution. }\end{array}$ & $\begin{array}{l}\text { Bioremediation can treat } \\
\text { large or small volumes, but } \\
\text { will require numerous } \\
\text { wells for larger volumes } \\
\text { due to a limited radius of } \\
\text { influence for substrate } \\
\text { distribution. }\end{array}$ \\
\hline $\begin{array}{l}\text { Cause risk during } \\
\text { construction or } \\
\text { operation? }\end{array}$ & $\begin{array}{l}\text { Primary risk would be from a significant amount of } \\
\text { necessary drilling. }\end{array}$ & $\begin{array}{l}\text { Primary risk would be } \\
\text { from a significant amount } \\
\text { of necessary drilling. }\end{array}$ \\
\hline
\end{tabular}

\subsubsection{Implementability}

\begin{tabular}{||l|l|l||}
\hline \multicolumn{1}{|c|}{$\begin{array}{c}\text { Implementability Screening } \\
\text { Criteria (see Table 5.1) }\end{array}$} & \multicolumn{1}{|c||}{ COC Group 1 } & \multicolumn{1}{c||}{ COC Group 2 } \\
\hline \hline $\begin{array}{l}\text { Reliably constructed and } \\
\text { operated? }\end{array}$ & $\begin{array}{l}\text { Uniform distribution of substrate with } \\
\text { a long well screen may be } \\
\text { problematic. Very large number of } \\
\text { wells necessary. }\end{array}$ & $\begin{array}{l}\text { Uniform distribution of substrate } \\
\text { with a long well screen may be } \\
\text { problematic. Very large number of } \\
\text { wells necessary. }\end{array}$ \\
\hline Reasonable consumable usage? & $\begin{array}{l}\text { Very large amounts of substrate } \\
\text { necessary for large treatment } \\
\text { volumes. }\end{array}$ & $\begin{array}{l}\text { Very large amounts of substrate } \\
\text { necessary for large treatment } \\
\text { volumes. }\end{array}$ \\
\hline \hline
\end{tabular}




\subsubsection{Relative Cost}

Cost factors for anaerobic bioremediation are a function of well costs, the amount of substrate required to maintain appropriate conditions over the desired treatment volume, and the longevity of the substrate. Long-duration substrates can only be distributed a short distance from injection wells. Thus, use of vegetable oil or similar long-duration substrates would be limited to small volumes because the cost for injection wells would render bioremediation much more expensive than other potential options at larger volumes. For instance, assuming a 7-m effective radius for vegetable oil injection stimulating bioremediation within a radius of influence of $14 \mathrm{~m}$, nine wells per acre are necessary. Soluble substrates can be distributed over larger volumes but are not long lasting and would require frequent injection. Thus, use of soluble substrates would also be limited to relatively small volumes because the cost of substrate injection via groundwater recirculation wells at large volumes would render bioremediation much more expensive than other potential options.

\subsubsection{Permeable Reactive Barriers}

Permeable reactive barrier (PRB) technology is an interception technology designed to treat contaminant as it passes through the treatment zone. This technology relies on having sufficient knowledge of the contaminant plume location and the groundwater flow paths. In general, PRB may act on the contaminants flowing through by destroying the contaminant in a reaction (biological or abiotic), by adsorption of the contaminant onto the PRB media, or by precipitation resulting from a chemical reaction. The PRB technology may be implemented as a funnel-and-gate system or an interception wall. The funnel-andgate system uses physical barriers (e.g., sheet piling or a low-permeability material such as a clay or grout) on two sides to direct groundwater (and contaminant plume) flow through a smaller permeable treatment zone. An interception wall is a continuous treatment zone wide enough to intersect with the expected span of the contaminant plume. The groundwater flow velocity controls the duration of the remediation effort and the design of the PRB. The PRB must be designed with a suitable thickness (or multiple walls in series) to provide enough residence time for reaction (destruction), adsorption, or precipitation of the contaminant to, at, or below the desired downgradient concentration. A funnel-andgate system is impractical to install for the depth and extent of the contamination and will not be considered further. The specific PRB variants are discussed in more detail below.

\subsubsection{Zero-Valent Iron PRB}

Zero-valent iron is most often installed in a trench-and-fill system but also can be installed by injection of material into the aquifer through wells. Present technology permits placement of small-scale iron particles from wells to radial distances of about 3-7 m (GeoSierra 2005). Similarly, low radial influences are observed with current applications of emulsified zero-valent iron (Quinn et al. 2005 and personal communication, J. Quinn). Emplacement of zero-valent iron particles in the subsurface provides an electron source for reduction of chromium, technetium-99, uranium, and nitrate.

Based on the evaluation of effectiveness, implementability, and relative cost presented below, zerovalent iron as a PRB is eliminated as a potential remediation method for all COC Groups (see Sections 7.2.10.1.1 through 7.2.10.1.3). 


\subsection{Effectiveness}

\begin{tabular}{||l|l|l||}
\hline \multicolumn{1}{|c|}{$\begin{array}{c}\text { Effectiveness Screening Criteria } \\
\text { (see Table 5.1) }\end{array}$} & \multicolumn{1}{c||}{ COC Group 1 } & \multicolumn{1}{c||}{ COC Group 2 } \\
\hline \hline Reliably meet goal? & $\begin{array}{l}\text { Likely reliable for chromium. } \\
\text { Tc-99 and uranium likely reduced } \\
\text { to meet goal, but can re-oxidize } \\
\text { over time. }\end{array}$ & $\begin{array}{l}\text { Likely reliable for nitrate. } \\
\text { Not applicable to cyanide. }\end{array}$ \\
\hline Produce hazardous products? & No hazardous byproducts. & No hazardous byproducts. \\
\hline Negatively impact to other COC? & No negative impacts expected. & No negative impacts expected. \\
\hline Treat target volume? & $\begin{array}{l}\text { A PRB could be emplaced at the } \\
\text { downgradient edge of a selected } \\
\text { treatment volume. }\end{array}$ & $\begin{array}{l}\text { A PRB could be emplaced at the } \\
\text { downgradient edge of a selected } \\
\text { treatment volume. }\end{array}$ \\
\hline $\begin{array}{l}\text { Cause risk during construction or } \\
\text { operation? }\end{array}$ & $\begin{array}{l}\text { Primary risk would be from } \\
\text { significant amount of necessary } \\
\text { drilling. }\end{array}$ & $\begin{array}{l}\text { Primary risk would be from } \\
\text { significant amount of necessary } \\
\text { drilling. }\end{array}$ \\
\hline
\end{tabular}

\subsection{Implementability}

\begin{tabular}{||l|l|l||}
\hline \hline $\begin{array}{c}\text { Implementability Screening Criteria } \\
\text { (see Table 5.1) }\end{array}$ & \multicolumn{1}{|c||}{ COC Group 1 } & \multicolumn{1}{c||}{ COC Group 2 } \\
\hline \hline Reliably constructed and operated? & $\begin{array}{l}\text { Uniform distribution of iron } \\
\text { with a long well screen may be } \\
\text { problematic. Very large } \\
\text { number of wells necessary. }\end{array}$ & $\begin{array}{l}\text { Uniform distribution of iron with a } \\
\text { long well screen may be problematic. } \\
\text { Very large number of wells necessary. }\end{array}$ \\
\hline Reasonable consumable usage? & $\begin{array}{l}\text { Very large amounts of iron } \\
\text { necessary for even moderate } \\
\text { barrier lengths. }\end{array}$ & $\begin{array}{l}\text { Very large amounts of iron necessary } \\
\text { for even moderate barrier lengths. }\end{array}$ \\
\hline
\end{tabular}

\subsection{Relative Cost}

Cost factors for zero-valent iron are associated with the relatively high reagent usage and large number of wells needed due to the limited radius of injection. Nano-zero-valent iron in powder form costs over \$16 per pound, and emulsified zero-valent iron costs more than $\$ 20$ per gallon for a $10 \%$ iron solution (personal communication, J. Greg Booth, Applied Science \& Advanced Technologies, Inc.). The cost of the emulsified zero-valent iron for a PRB of $300 \mathrm{~m}$ over a depth interval of $20 \mathrm{~m}$, assuming a radial influence of $7 \mathrm{~m}$ per well and only one line of injection wells (total of about 22 wells), would be on the order of more than \$200M.

\subsubsection{In Situ Redox Manipulation PRB}

In situ redox manipulation (ISRM) involves the injection of a reducing solution (e.g., sodium dithionite) and the creation of a zone of ferrous iron that can facilitate the chemical reduction of the contaminants. After the reducing solution has been injected and allowed to react with the aquifer sediments, the solution is extracted from the aquifer to remove unreacted reagent, sulfate, etc. The ferrous iron created by reaction with the reagent remains in place and reacts to reduce contaminants and oxygen or oxidized solutes carried into the barrier. In addition to the general PRB design issues of 
groundwater flow path and barrier thickness, key properties that determine the effectiveness/ implementability of ISRM are the hydraulic conductivity of the aquifer and the natural iron content of the aquifer sediments. The hydraulic conductivity of the aquifer affects the ability and rate of distribution of the reagent. The amount of natural iron in the aquifer sediments affects the distribution of the reagent and the resulting reactivity of the barrier. Too little iron will result in an ineffective reducing barrier, and too much iron will result in fast consumption of the reagent and a correspondingly small radius of influence. A proof-of-principle test at the Hanford Site had an apparent radius of influence of about $8 \mathrm{~m}$ (DOE 2000). An ISRM PRB in the subsurface provides an electron source for reduction of chromium, technetium-99, uranium, and nitrate.

Based on the evaluation of effectiveness, implementability, and relative cost presented below, ISRM as a PRB is retained as a potential remediation method for COC groups 1 and 2 (see Sections 7.2.10.2.1 through 7.2.10.2.3).

\subsection{Effectiveness}

\begin{tabular}{||l|l|l||}
\hline \multicolumn{1}{|c|}{$\begin{array}{c}\text { Effectiveness Screening Criteria } \\
\text { (see Table 5.1) }\end{array}$} & \multicolumn{1}{c||}{ COC Group 1 } & \multicolumn{1}{c||}{ COC Group 2 } \\
\hline \hline Reliably meet goal? & $\begin{array}{l}\text { Likely reliable for chromium. } \\
\text { Tc-99 and uranium likely } \\
\text { reduced to meet goal, but can re- } \\
\text { oxidize over time. }\end{array}$ & $\begin{array}{l}\text { Likely reliable for nitrate. } \\
\text { Not applicable to cyanide. }\end{array}$ \\
\hline Produce hazardous products? & No hazardous byproducts. & No hazardous byproducts. \\
\hline $\begin{array}{l}\text { Negatively impact to other } \\
\text { COC? }\end{array}$ & No negative impacts expected. & No negative impacts expected. \\
\hline Treat target volume? & $\begin{array}{l}\text { A PRB could be emplaced at the } \\
\text { downgradient edge of a selected } \\
\text { treatment volume. }\end{array}$ & $\begin{array}{l}\text { A PRB could be emplaced at the } \\
\text { downgradient edge of a selected } \\
\text { treatment volume. }\end{array}$ \\
\hline $\begin{array}{l}\text { Cause risk during construction } \\
\text { or operation? }\end{array}$ & $\begin{array}{l}\text { Primary risk would be from } \\
\text { significant amount of necessary } \\
\text { drilling. }\end{array}$ & $\begin{array}{l}\text { Primary risk would be from } \\
\text { significant amount of necessary } \\
\text { drilling. }\end{array}$ \\
\hline \hline
\end{tabular}

\subsection{Implementability}

\begin{tabular}{||l|l|l||}
\hline \multicolumn{1}{|c|}{$\begin{array}{c}\text { Implementability Screening } \\
\text { Criteria (see Table 5.1) }\end{array}$} & \multicolumn{1}{|c||}{ COC Group 1 } & \multicolumn{1}{c||}{ COC Group 2 } \\
\hline \hline $\begin{array}{l}\text { Reliably constructed and } \\
\text { operated? }\end{array}$ & $\begin{array}{l}\text { Uniform distribution of reagent } \\
\text { (e.g., dithionite) with a long } \\
\text { well screen may be problematic. } \\
\text { Very large number of wells } \\
\text { necessary. }\end{array}$ & $\begin{array}{l}\text { Uniform distribution of reagent } \\
\text { (e.g., dithionite) with a long } \\
\text { well screen may be problematic. } \\
\text { Very large number of wells } \\
\text { necessary. }\end{array}$ \\
\hline Reasonable consumable usage? & $\begin{array}{l}\text { Very large amounts of reagent } \\
\text { (e.g., dithionite)necessary for } \\
\text { even moderate barrier lengths. }\end{array}$ & $\begin{array}{l}\text { Very large amounts of reagent } \\
\text { (e.g., dithionite)necessary for } \\
\text { even moderate barrier lengths. }\end{array}$ \\
\hline
\end{tabular}




\subsection{Relative Cost}

The cost factors for ISRM are the costs for drilling, reagent, and the frequency of re-injection. Using a presumed radius of influence of $8 \mathrm{~m}$ per well, the total reducing solution volume as a function of depth is shown in Table 7.6. At a cost of $\$ 0.625 /$ gal for this solution (Envirochem Technology Services), the cost of the dithionite for a PRB of $300 \mathrm{~m}$ over a depth interval of $20 \mathrm{~m}$, assuming a radial influence of 8 m per well and two lines of injection wells (total of about 36 wells), would be on the order of \$3.2M.

Table 7.6. Volume of Dithionite Solution as a Function of Treatment Depth

\begin{tabular}{||l|c|c||}
\hline Treatment Depth & $\begin{array}{c}\text { Volume of Aquifer } \\
\left(\mathrm{m}^{3}\right)\end{array}$ & $\begin{array}{c}\text { Volume of Dithionite } \\
\text { (gal) }\end{array}$ \\
\hline \hline $15 \mathrm{~m}$ & 3016 & 239,000 \\
\hline $20 \mathrm{~m}$ & 4021 & 319,000 \\
\hline $30 \mathrm{~m}$ & 6032 & 478,000 \\
\hline $\begin{array}{l}\text { (a) Calculated with an 8-m radius of influence. } \\
\text { (b) Calculated using a porosity of } 0.3 \text { and for dithionite filling 100\% of } \\
\text { the pore space. }\end{array}$ \\
\hline
\end{tabular}

\subsubsection{In Situ Anaerobic Bioremediation PRB}

Nitrate, chromium, technetium-99, and uranium can be reduced under anaerobic conditions and converted to non-hazardous products (for nitrate) or to insoluble chemical forms (for chromium, technetium-99, and uranium). The biomass that grows during anaerobic bioremediation may also increase the adsorption of other contaminants such as iodine-129, potentially enhanced through reduction of the iodine. Thus, anaerobic bioremediation is potentially applicable to COC Groups 1, and 2.

The success in stimulating dechlorination without producing hazardous byproducts and contaminant reduction versus other types of anaerobic activity is dependent on the microbial ecology and groundwater geochemistry (e.g., presence of other electron acceptors). The ability to stimulate appropriate microbial activity would need to be evaluated to confirm whether remediation goals will likely be met.

An in situ anaerobic bioremediation PRB would be implemented by distributing a long-duration substrate such as vegetable oil into the aquifer. Because the substrate is less accessible to the bacteria, it is not consumed as it is distributed and can provide a long-term food supply once in place. The key property with this technology is the hydraulic conductivity of the aquifer. The radius of the treatment zone depends on how well the substrate can be injected into and distributed through the aquifer formation. A secondary property of interest is the length of time that the substrate lasts, which impacts the frequency of "regenerating" the treatment zone. The radius of influence for long-duration substrate injection used for the screening evaluation is about $7 \mathrm{~m}$ for oil distribution, similar to what has been achieved for other applications of this technology.

Based on the evaluation of effectiveness, implementability, and relative cost (presented below), anaerobic bioremediation as a PRB is retained as a potential remediation method for COC groups 1 and 2 (see Sections 7.2.10.3.1 through 7.2.10.3.3). 


\subsection{Effectiveness}

\begin{tabular}{|c|c|c|}
\hline $\begin{array}{l}\text { Effectiveness Screening } \\
\text { Criteria (see Table 5.1) }\end{array}$ & COC Group 1 & COC Group 2 \\
\hline Reliably meet goal? & $\begin{array}{l}\text { There is moderate uncertainty in meeting the } \\
\text { goals for Tc-99 and uranium because these } \\
\text { compounds can reoxidize readily and become } \\
\text { mobile again after being microbially reduced } \\
\text { and temporarily immobilized. It is likely that } \\
\text { goals for chromium could be met because it } \\
\text { remains stable and immobile after microbial } \\
\text { reduction. Increased adsoption of I-129 and } \\
\text { reduction may also occur. }\end{array}$ & $\begin{array}{l}\text { It is likely that goals for nitrate could } \\
\text { be met because it will likely be } \\
\text { reduced to nitrogen gas. } \\
\text { Not applicable to cyanide. }\end{array}$ \\
\hline $\begin{array}{l}\text { Produce hazardous } \\
\text { products? }\end{array}$ & No hazardous byproducts. & Likely no hazardous byproducts. \\
\hline $\begin{array}{l}\text { Negatively impact to } \\
\text { other COC? }\end{array}$ & No negative impacts expected. & No negative impacts expected. \\
\hline Treat target volume? & $\begin{array}{l}\text { Bioremediation can be applied as a treatment } \\
\text { barrier, but will require numerous wells for } \\
\text { long barriers due to a limited radius of } \\
\text { influence for substrate distribution. The rate } \\
\text { of biological reactions would need to be } \\
\text { sufficient to treat the contaminants within the } \\
\text { residence item of the barrier. Thus, the design } \\
\text { must consider the necessary barrier thickness. }\end{array}$ & $\begin{array}{l}\text { Bioremediation can be applied as a } \\
\text { treatment barrier, but will require } \\
\text { numerous wells for long barriers due } \\
\text { to a limited radius of influence for } \\
\text { substrate distribution. The rate of } \\
\text { biological reactions would need to be } \\
\text { sufficient to treat the contaminants } \\
\text { within the residence item of the } \\
\text { barrier. Thus, the design must } \\
\text { consider the necessary barrier } \\
\text { thickness. }\end{array}$ \\
\hline $\begin{array}{l}\text { Cause risk during } \\
\text { construction or } \\
\text { operation? }\end{array}$ & $\begin{array}{l}\text { Primary risk would be from significant } \\
\text { amount of necessary drilling. }\end{array}$ & $\begin{array}{l}\text { Primary risk would be from } \\
\text { significant amount of necessary } \\
\text { drilling. }\end{array}$ \\
\hline
\end{tabular}

\subsection{Implementability}

\begin{tabular}{||l|l|l||}
\hline \multicolumn{1}{|c|}{$\begin{array}{c}\text { Implementability Screening } \\
\text { Criteria (see Table 5.1) }\end{array}$} & \multicolumn{1}{|c||}{ COC Group 1 } & \multicolumn{1}{c||}{ COC Group 2 } \\
\hline \hline $\begin{array}{l}\text { Reliably constructed and } \\
\text { operated? }\end{array}$ & $\begin{array}{l}\text { Uniform distribution of } \\
\text { substrate with a long well screen } \\
\text { may be problematic. Very large } \\
\text { number of wells necessary. }\end{array}$ & $\begin{array}{l}\text { Uniform distribution of } \\
\text { substrate with a long well screen } \\
\text { may be problematic. Very large } \\
\text { number of wells necessary. }\end{array}$ \\
\hline Reasonable consumable usage? & $\begin{array}{l}\text { Very large amounts of substrate } \\
\text { necessary for long barriers. }\end{array}$ & $\begin{array}{l}\text { Very large amounts of substrate } \\
\text { necessary for long barriers. }\end{array}$ \\
\hline
\end{tabular}

\subsection{Relative Cost}

Cost factors for anaerobic bioremediation are a function of well costs, the amount of substrate required to maintain appropriate conditions within the barrier, and the longevity of the substrate. Longduration substrates can only be distributed a short distance from injection wells. However, substrate volume and costs are likely similar or lower than those for other PRB reagents (e.g., ISRM). 


\subsubsection{Injectable Apatite Barrier}

Hydroxyapatite [ $\left.\mathrm{Ca}_{5}\left(\mathrm{PO}_{4}\right)_{3} \mathrm{OH}\right]$ has been found to be very effective in sequestration of many dissolved metals including strontium and uranium. Such divalent metal oxyanions do react with dissolved phosphate to precipitate and immobilize the heavy metal. Apatite sequestration is expected to be minimally effective with chromium, technetium, and iodine groundwater contamination. Additionally, PRBs were not considered for the immobile COC. Thus, for the screening evaluation, apatite was only considered for applicable to uranium as part of COC Group 1 (Fuller et al. 2002; Flury and Harsh 2000; Bostick et al. 2003). Because of the depth to groundwater, application of solid phase apatite is not feasible and will not be considered as a viable technology for the site. However, apatite minerals can be formed in situ from injection of soluble reagents (Moore et al. 2004). This method relies on injection of calcium citrate and phosphate solutions. The calcium is complexed with citrate during the injection and does not reaction with the phosphate until the citrate is degraded by microorganisms in the subsurface. Thus, the apatite formation can be distributed over a radial distance of meters to $\sim 10 \mathrm{~m}$ away from the injection well depending on the subsurface hydrology and the microbial citrate degradation rate. This technique is currently being tested for application to strontium contamination at the Hanford 100-N Area. Injectable apatite would be considered an innovative treatment option.

Based on the evaluation of effectiveness, implementability, and relative cost presented below, injectable apatite is retained as a potential remediation method for uranium (part of COC Group 1) as a barrier (see Sections 7.2.10.4.1 through 7.2.10.4.3). This is an innovative technology that would likely need treatability testing.

\subsection{Effectiveness}

\begin{tabular}{||l|l||}
\hline $\begin{array}{l}\text { Effectiveness Screening Criteria } \\
\text { (see Table 5.1) }\end{array}$ & \multicolumn{1}{c|}{ COC Group 1 (uranium only) } \\
\hline \hline Reliably meet goal? & $\begin{array}{l}\text { Likely reliable to reduce concentrations as a barrier. Laboratory- } \\
\text { scale studies show promise. Field-scale testing yet to be conducted. }\end{array}$ \\
\hline Produce hazardous products? & No hazardous byproducts are produced. \\
\hline $\begin{array}{l}\text { Negatively impact to other } \\
\text { COC? }\end{array}$ & $\begin{array}{l}\text { Likely no impact if applied as a barrier for the uranium plume. } \\
\text { Residual phosphate could stimulate microbiological growth. }\end{array}$ \\
\hline Treat target volume? & $\begin{array}{l}\text { Distribution of the reagents meters to 10 m from the injection point } \\
\text { is expected. As such a barrier application similar to an anaerobic } \\
\text { biobarrier is likely possible. }\end{array}$ \\
\hline $\begin{array}{l}\text { Cause risk during construction } \\
\text { or operation? }\end{array}$ & Construction risk would be from drilling necessary. \\
\hline \hline
\end{tabular}

\subsection{Implementability}

\begin{tabular}{||l|l||}
\hline $\begin{array}{c}\text { Implementability } \\
\text { Screening Criteria (see } \\
\text { Table 5.1) }\end{array}$ & \multicolumn{1}{||}{ COC Group 1 (uranium only) } \\
\hline \hline $\begin{array}{l}\text { Reliably constructed and } \\
\text { operated? }\end{array}$ & $\begin{array}{l}\text { Uniform distribution of reagents possible with proper engineering and } \\
\text { hydraulic control. Treatability testing is needed. }\end{array}$ \\
\hline $\begin{array}{l}\text { Reasonable consumable } \\
\text { usage? }\end{array}$ & Treatability testing is needed to assess design of the remediation system. \\
\hline \hline
\end{tabular}




\subsection{Relative Cost}

The injectable apatite remediation method is an innovative technology still under development. Cost factors are primarily related to the radius of influence that can be obtained. It is expected that a radius of influence similar to injection of a long-duration substrate for anaerobic bioremediation will be possible. As such, costs for injectable apatite could be comparable to other technologies for a barrier where well costs would be similar to an anaerobic bioremediation biobarrier.

\subsubsection{Polyphosphate Barrier}

Another phosphate-based technology for stabilization of uranium using phosphate is presently in development. This technology uses injection of liquid polyphosphate to stabilize uranium. It is not applicable to the other COC. This technology stabilizes uranium by a different mechanism than apatite stabilization.

The process uses polymers of phosphate to release phosphate at a slow, controlled rate into groundwater downgradient of the application point. The presence of phosphate in groundwater, even in minor concentrations $\left(10^{-8} \mathrm{M}\right)$, promotes the formation of autunite-group minerals, $\mathrm{X}_{3-\mathrm{n}}{ }^{(\mathrm{n})^{*}}\left[\left(\mathrm{UO}_{2}\right)\left(\mathrm{PO}_{4}\right)\right]_{2} \cdot \mathrm{XH}_{2} \mathrm{O}$, thereby limiting the mobility of the uranyl cation $\left(\mathrm{UO}_{2}{ }^{2+}\right)$ in the subsurface environment. The use of soluble long-chain polyphosphate reagent delays precipitation of the autunite, thereby mitigating plugging of the formation near the application point. By adjusting the length of the polyphosphate chain, the hydrolysis reaction that releases the phosphate into the water can be engineered and the uranium stabilization rate controlled. Because autunite sequesters uranium in the oxidized form, $\mathrm{U}^{6+}$, rather than forcing reduction to $\mathrm{U}^{4+}$, the possibility of re-oxidation and subsequent re-mobilization is negated. Extensive laboratory testing demonstrates the very low solubility of autunite. In addition to autunite, excess phosphorous may result in apatite mineral formation, providing a secondary, long-term source of treatment capacity.

Deployment polyphosphate may be designed to treat a horizontal extent as well as vertical zone of uranium in the groundwater and at the water-table interface. The liquid form of the reagent facilitates application to and transport within the contaminated groundwater plume. Uranium transport studies in columns packed with contaminated sediment from the Hanford 300 Area indicate that a polyphosphate solution reduces the concentration of uranium in water to near the drinking water standard $(30 \mu \mathrm{g} / \mathrm{L})$ (Wellman et al. 2006). Polyphosphate would be considered an innovative treatment option.

Based on the evaluation of effectiveness, implementability, and relative cost presented below, polyphosphate is retained as a potential remediation method for uranium (part of COC Group 1) as a barrier (see Sections 7.2.10.5.1 through 7.2.10.5.3). This is an innovative technology that would likely need treatability testing. 


\subsection{Effectiveness}

\begin{tabular}{||l|l||}
\hline \multicolumn{1}{|c|}{$\begin{array}{c}\text { Effectiveness Screening } \\
\text { Criteria (see Table 5.1) }\end{array}$} & \multicolumn{1}{c||}{ COC Group 1 (uranium only) } \\
\hline \hline Reliably meet goal? & $\begin{array}{l}\text { Likely reliable to reduce concentrations as a barrier. Laboratory-scale } \\
\text { studies show promise. Field-scale testing yet to be conducted. }\end{array}$ \\
\hline Produce hazardous products? & No hazardous byproducts are produced. \\
\hline $\begin{array}{l}\text { Negatively impact to other } \\
\text { COC? }\end{array}$ & $\begin{array}{l}\text { Likely no impact if applied as a barrier for the uranium plume. } \\
\text { Residual phosphate could stimulate microbiological growth. }\end{array}$ \\
\hline Treat target volume? & $\begin{array}{l}\text { Distribution of the polyphosphate meters to } 10 \text { m from the injection } \\
\text { point is expected. As such a barrier application similar to an anaerobic } \\
\text { biobarrier is likely possible. }\end{array}$ \\
\hline $\begin{array}{l}\text { Cause risk during construction } \\
\text { or operation? }\end{array}$ & Construction risk would be from drilling necessary. \\
\hline \hline
\end{tabular}

\subsection{Implementability}

\begin{tabular}{||l|l||}
\hline \hline $\begin{array}{c}\text { Implementability Screening } \\
\text { Criteria (see Table 5.1) }\end{array}$ & \multicolumn{1}{|c||}{ COC Group 1 (uranium only) } \\
\hline \hline $\begin{array}{l}\text { Reliably constructed and } \\
\text { operated? }\end{array}$ & $\begin{array}{l}\text { Uniform distribution of polyphosphate possible with proper } \\
\text { engineering and hydraulic control. Treatability testing is needed. }\end{array}$ \\
\hline $\begin{array}{l}\text { Reasonable consumable } \\
\text { usage? }\end{array}$ & $\begin{array}{l}\text { Treatability testing is needed to assess design of the remediation } \\
\text { system. }\end{array}$ \\
\hline \hline
\end{tabular}

\subsection{Relative Cost}

The polyphosphate remediation method is an innovative technology still under development. Cost factors are primarily related to the radius of influence that can be obtained. It is expected that a radius of influence similar to injection of a long-duration substrate for anaerobic bioremediation will be possible. As such, costs for polyphosphate could be comparable to other technologies as a barrier where well costs would be similar to an anaerobic bioremediation biobarrier. 


\subsection{Results of Screening Evaluation}

Based on the screening evaluation criteria, potential remediation methods were comparatively evaluated to identify those most promising for continued evaluation as part of the feasibility study. Only a few methods are applicable to all COC. Thus, identification of the most promising potential remediation methods is categorized by COC group. Multiple scales of application may be useful for the overall remediation efforts in the 200-BP-5 Operable Unit. For this reason, identification of the most promising potential remediation methods is also categorized by the scales of application identified in the effectiveness evaluation criteria (Table 5.1). Using this matrix of most promising potential remediation methods provides information to support either use of a single remedy or a "treatment train" approach as part of the feasibility study. Table 8.1 lists the potential remediation methods recommended for further assessment in the subsequent feasibility study as a function of both COC group and scale of application. 
Table 8.1. Summary of Potential Remediation Methods Recommended for Further Assessment for Each COC Grouping Based on the Results of the Screening Evaluation

\begin{tabular}{|c|c|c|c|}
\hline Target & COC Group 1 & COC Group 2 & COC Group 3 \\
\hline $\begin{array}{l}\text { Continuing Source ( }<1 \text { acre) } \\
\text { (areal extent over thickness of } \\
\text { plume defined in Section 2) }\end{array}$ & $\begin{array}{ll}\text { - } & \text { Pump-and-Treat } \\
\text { - } & \text { MNA } \\
\text { Anaerobic Bioremediation (chromium, Tc-99, and } \\
\text { - } & \text { Ananium) } \\
& \text { Tc-99, and uranium) } \\
\text { - } & \text { ISRM as a PRB (chromium, Tc-99, and uranium) } \\
\text { - } & \text { Injectable Apatite (uranium and plutonium) } \\
\text { - } & \text { Polyphosphate (uranium) } \\
\text { - } & \text { Injectable Apatite Barrier (uranium) } \\
& \text { Polyphosphate Barrier (uranium) } \\
\end{array}$ & $\begin{array}{ll}\text { - } & \text { Pump-and-Treat } \\
\text { - } & \text { MNA } \\
\text { - } & \text { Anaerobic Bioremediation (nitrate) } \\
\text { - } & \text { Anaerobic Bioremediation as a PRB } \\
\text { (nitrate) } \\
\text { - } & \text { ISRM as a PRB (nitrate) }\end{array}$ & $\begin{array}{l}\text { - } \quad \text { Pump-and-Treat } \\
\text { MNA }\end{array}$ \\
\hline $\begin{array}{l}\text { High Concentrations } \\
(<5 \text { acres) } \\
\text { (areal extent over thickness of } \\
\text { plume defined in Section 2) }\end{array}$ & $\begin{array}{ll}\text { - } & \text { Pump-and-Treat } \\
\text { - } & \text { MNA } \\
\text { - } & \text { Anaerobic Bioremediation (chromium, Tc-99, and } \\
\text { - } & \text { Ananium) } \\
& \text { Tc-99, and uranium) } \\
\text { - } & \text { ISRM as a PRB (chromium, Tc-99, and uranium) } \\
\text { - } & \text { Injectable Apatite (uranium) } \\
\text { - } & \text { Polyphosphate (uranium) } \\
\text { - } & \text { Injectable Apatite Barrier (uranium) } \\
\text { - } & \text { Polyphosphate Barrier (uranium) }\end{array}$ & $\begin{array}{ll}\text { - } & \text { Pump-and-Treat } \\
\text { - } & \text { MNA } \\
\text { - } & \text { Anaerobic Bioremediation (nitrate) } \\
\text { - } & \text { Anaerobic Bioremediation as a PRB } \\
& \text { (nitrate) } \\
\text { - } & \text { ISRM as a PRB (nitrate) }\end{array}$ & $\begin{array}{ll}\text { - } & \text { Pump-and-Treat } \\
\text { - } & \text { MNA }\end{array}$ \\
\hline $\begin{array}{l}\text { Low or High Concentrations } \\
\text { ( } 25 \text { acres) } \\
\text { (areal extent over thickness of } \\
\text { plume defined in Section 2) }\end{array}$ & $\begin{array}{ll}\text { - } & \text { Pump-and-Treat } \\
\text { - } & \text { MNA } \\
\text { - } & \text { Anaerobic Bioremediation (chromium, Tc-99, and } \\
& \text { uranium) } \\
\text { - } & \text { Anaerobic Bioremediation as a PRB (chromium, } \\
& \text { Tc-99, and uranium) } \\
\text { - } & \text { ISRM as a PRB (chromium, Tc-99, and uranium) } \\
\end{array}$ & $\begin{array}{ll}\text { - } & \text { Pump-and-Treat } \\
\text { - } & \text { MNA } \\
\text { - } & \text { Anaerobic Bioremediation (nitrate) } \\
\text { - } & \text { Anaerobic Bioremediation as a PRB } \\
& \text { (nitrate) } \\
\text { - } & \text { ISRM as a PRB (nitrate) }\end{array}$ & $\begin{array}{ll}\text { - } & \text { Pump-and-Treat } \\
\text { - } & \text { MNA }\end{array}$ \\
\hline $\begin{array}{l}\text { Low Concentrations ( } 250 \text { acres or } \\
\text { greater) } \\
\text { (areal extent over thickness of } \\
\text { plume defined in Section 2) }\end{array}$ & $\begin{array}{ll}\text { - } & \text { Pump-and-Treat } \\
\text { - } & \text { MNA } \\
\text { - } & \text { Anaerobic Bioremediation as a PRB (chromium, } \\
& \text { Tc-99, and uranium) } \\
\text { - } & \text { ISRM as a PRB (chromium, Tc-99, and uranium) }\end{array}$ & $\begin{array}{ll}\text { - } & \text { Pump-and-Treat } \\
\text { - } & \text { MNA } \\
\text { - } & \text { Anaerobic Bioremediation as a PRB } \\
\text { (nitrate) } \\
\text { - } & \text { ISRM as a PRB (nitrate) } \\
\end{array}$ & Not Applicable \\
\hline
\end{tabular}




\subsection{References}

Bostick WD, RJ Stevenson, LA Harris, D Peery, JR Hall, JL Shoemaker, Jarabek, and EB Munday. 2003. Use of Apatite for Chemical Stabilization of Subsurface Contaminants: Final Report. U.S. Department of Energy, National Energy Technology Laboratory, Washington, DC.

DOE. 2000. Innovative Technology Summary Report: In Situ Redox Manipulation. DOE/EM-0499, U.S. Department of Energy, Office of Environmental Management, Office of Science and Technology, Washington, D.C.

DOE. 2001. Groundwater Sampling and Analysis Plan for 200-BP-5 Operable Unit. DOE-RL-2001-49, Rev.1, U.S. Department of Energy, Richland Operations Office, Richland, Washington.

DOE. 1999. Frozen Soil Barrier. DOE/EM-0483, U.S. Department of Energy, Office of Environmental Management, Office of Science and Technology, Washington, D.C.

EPA. 1999. Use of Monitored Natural Attenuation at Superfund, RCRA Corrective Action, and Underground Storage Tank Sites. OSWER Directive 9200.4-17P, U.S. Environmental Protection Agency, Office of Solid Waste and Emergency Response, Washington, D.C.

EPA. 1988. Guidance for Conducting Remedial Investigations and Feasibility Studies under CERCLA Interim Final. EPA/540/G-89/004, U.S. Environmental Protection Agency, Office of Emergency and Remedial Response, Washington, D.C.

Flury M and JB Harsh. 2000. Remediation of Uranium Contaminated Mine Waste. State of Washington Water Research Center Report WRR-04, Olympia, Washington.

Fuller CC, MJ Piana, JR Bargar, JA Davis, and M Kohler 2002. "Evaluation of Apatite Materials for Use in Permeable Reactive Barriers for the Remediation of Uranium-Contaminated Groundwater.” In Handbook of Groundwater Remediation Using Permeable Reactive Barriers, Intenational Standard Book Number: 0-12-513563-7, Academic Press, San Diego, California.

GeoSierra. 2005. Newsletter, Spring/Summer 2005. 3560 Engineering Dr., Norcross, Georgia. Available online at http://www.geosierra.com/pdf/2005_spring_summer.pdf

Hartman MJ, LF Morasch, and WD Webber (eds.). 2006. Hanford Site Groundwater Monitoring for Fiscal Year 2005. PNNL-15670, Pacific Northwest National Laboratory, Richland, Washington.

Muramatsu Y, S Yoshida, U Fehn, S Amachi, and Y Ohmomo. 2004. "Studies with Natural and Anthropogenic Iodine Isotopes: Iodine Distribution and Cycling in the Global Environment.” J. Environ. Radioactivity 74:221-232.

Quinn J, C Geiger, C Clausen, K Brooks, C Coon, S O’Hara, T Krug, D Major, W-S Yoon, A Gavaskar, and T Holdsworth. 2005. "Field Demonstration of DNAPL Dehalogenation Using Emulsified ZeroValent Iron.” Environ. Sci. Technol. 39(5):1309-1318. 
Smith RM. 1980. 216-B-5 Reverse Well Characterization Study. RHO-ST-37. Rockwell International, Richland, WA.

Thorne PD, MP Bergeron, MD Williams and VL Freedman. 2006. Groundwater Data Package for Hanford Assessments. PNNL-14753 Rev 1, Pacific Northwest National Laboratory, Richland, Washington.

Wellman DM, JP Icenhower, AP Gamerdinger, SW Forrester. 2006. “Effects of pH, Temperature, and Aqueous Organic Material on the Dissolution Kinetics of Meta-Autunite Minerals, (Na, Ca)2-

1[(UO2)(PO4)]2·3H2O.” American Mineralogist 91:143-158.

Williams BA, BN Bjornstad, R Schalla, and WD Webber. 2000. Revised Hydrogeology for the Suprabasalt Aquifer System, 200-East Area and Vicinity, Hanford Site, Washington. PNNL-12261, Pacific Northwest National Laboratory, Richland, Washington. 


\section{Distribution}

No. of

Copies

ONSITE

4 DOE Richland Operations Office

B.L. Charboneau

J.G. Morse

A6-33

A6-38

DOE Public Reading Room (2)

DOE Office of River Protection

M.E. Burandt

3 Fluor Hanford, Inc.

G.S. Thomas

T.W. Fogwell

S.W. Petersen

H6-60

E6-35

E6-35
No. of

Copies

3 CH2M HILL Hanford Group, Inc.

F.J. Anderson

H6-03

F. Mann

H6-03

D.J. Meyer

S5-03

U. S. Environmental Protection Agency

D. Faulk

B1-46

3 Washington State Department of Ecology

D. Goswami

$\mathrm{H} 0-57$

Z. Jackson-Maine

$\mathrm{H} 0-57$

J. Price

$\mathrm{H} 0-57$
5 Pacific Northwest National Laboratory G.V. Last

K6-81

M.J. Truex (2)

K6-96

Hanford Technical Library (2)
P8-55 